\title{
A glass workshop in 'Aqir, Israel and a new type of compositional contamination
}

\author{
Chen Chen ${ }^{{ }^{*}}$, Ian C. Freestone ${ }^{a}$, Yael Gorin-Rosen ${ }^{b}$, Patrick S. Quinn ${ }^{\text {a }}$ \\ ${ }^{a}$ University College London, Institute of Archaeology, 31-34 Gordon Square, London WC1H OPY, UK \\ ${ }^{b}$ Israel Antiquities Authority, POB 586, Jerusalem 91004, Israel \\ *Corresponding author. E-mail address: chen.chen.17@ucl.ac.uk (C. Chen).
}

\begin{abstract}
Materials associated with a secondary workshop of early Byzantine date (4th-5th centuries) were unearthed in excavations by the Israel Antiquities Authority in 'Aqir, central Israel. Fragments of furnace structure, production debris and glass vessels have been analysed by scanning electron microscopy with energy dispersive X-ray analysis (SEM-EDS) and thin-section petrography.
\end{abstract}

The results suggest that the workshop melted raw glass chunks of similar composition to the primary glass made at Apollonia, Israel, to produce secondary glass products. Some glass vessels associated with the furnace are of different composition, and some of these may represent material brought in as cullet for recycling. The furnace was built with ceramic bricks comprising alluvial-type clay with inclusions of quartz sand, probably added as temper. It was fired by potash-rich fuel to approximately $1100^{\circ} \mathrm{C}$. Lime mortar was used either to cement the gaps between mudbricks or to line the furnace as a parting layer, and it has introduced a previously unrecognised type of contamination in glass of the period, mainly of $\mathrm{Fe}_{2} \mathrm{O}_{3}$ and $\mathrm{CaO}$. The contamination may be identified in glass vessel assemblages elsewhere but is not ubiquitous. As its origin relates to the furnace structure, its occurrence may depend upon chronology or geography and further work is needed to resolve this issue.

Keywords: The Levant; Byzantine; Glass-working; Glass furnace; Technology; SEM-EDS; Thin-section petrography; Provenance 


\section{Introduction}

The trade and technology of ancient glass have attracted significant attention in the literature but the investigation of glassmaking and glassworking furnaces is largely limited to their forms. With a few notable exceptions (e.g. Rehren, 1997; Jackson et al., 1998; Jackson et al., 2003; Paynter, 2008 as well as the pioneering study into LBA materials by Turner, 1954) plus some work on post-Medieval materials (e.g. Eramo, 2005; Eramo, 2006; Dungworth, 2008), the structural and container materials have not been well investigated, and their interactions with the bulk glass have received limited attention. However, the selection and preparation of structural and container materials offers potential insights into the practices of the craftspeople and the diffusion and transfer of technological know-how, while compositional modification of the glass may affect the interpretation of provenance and workshop processes such as recycling (Jackson and Paynter, 2016; Barfod et al., 2018; AlBashaireh et al., 2016a). The present paper offers a contribution to this under-researched area.

The eastern Mediterranean coastal strip was an important centre of glass production in the first millennium CE. Levantine glass, identified by its chemical and isotopic composition (Freestone et al., 2000; Ganio et al., 2012), is found across the ancient world (e.g. Foster and Jackson, 2009; Schibille et al., 2017; Ares et al., 2019). In spite of extensive excavation of both primary (glass-making) and secondary (glass-working) production sites, the materials science investigation of the furnace installations, debris and associated process has been limited. In the present study, we investigate the debris from a Byzantine glass-working furnace in Israel. The results pose interesting questions about the structure of the furnace and the possible use of a lime-rich release agent or protective layer, and also indicate a previously unreported source of contamination of the glass, which can explain compositional features of glass vessels from some consumer assemblages.

\section{Materials and Methods}

The installation under investigation was uncovered in a salvage excavation carried out in 'Aqir Village, Qiryat 'Eqron, Central District of Israel (License number: A-6758, Fig. 1) in the year 2013 (Marmelstein, 2016). In the Roman Period 'Aqir village was named Accaron and inhabited by Jews, according to Eusebius of Caesarea (around $324 \mathrm{CE}$, translated by Wolf, 1971); it was recorded as a settlement called Akkar on the Madaba Map in Jordan in 
542 CE (Donner, 1992). The larger area, Palaestina Prima was lost by its Byzantine rulers to a joint army of Sassanians and Jews during 614-628 CE (Greatrex and Lieu, 2005). Although the Byzantine rulers took their territory back in $628 \mathrm{CE}$, they gradually and irreversibly lost it to the Arabs in 634-636 CE.
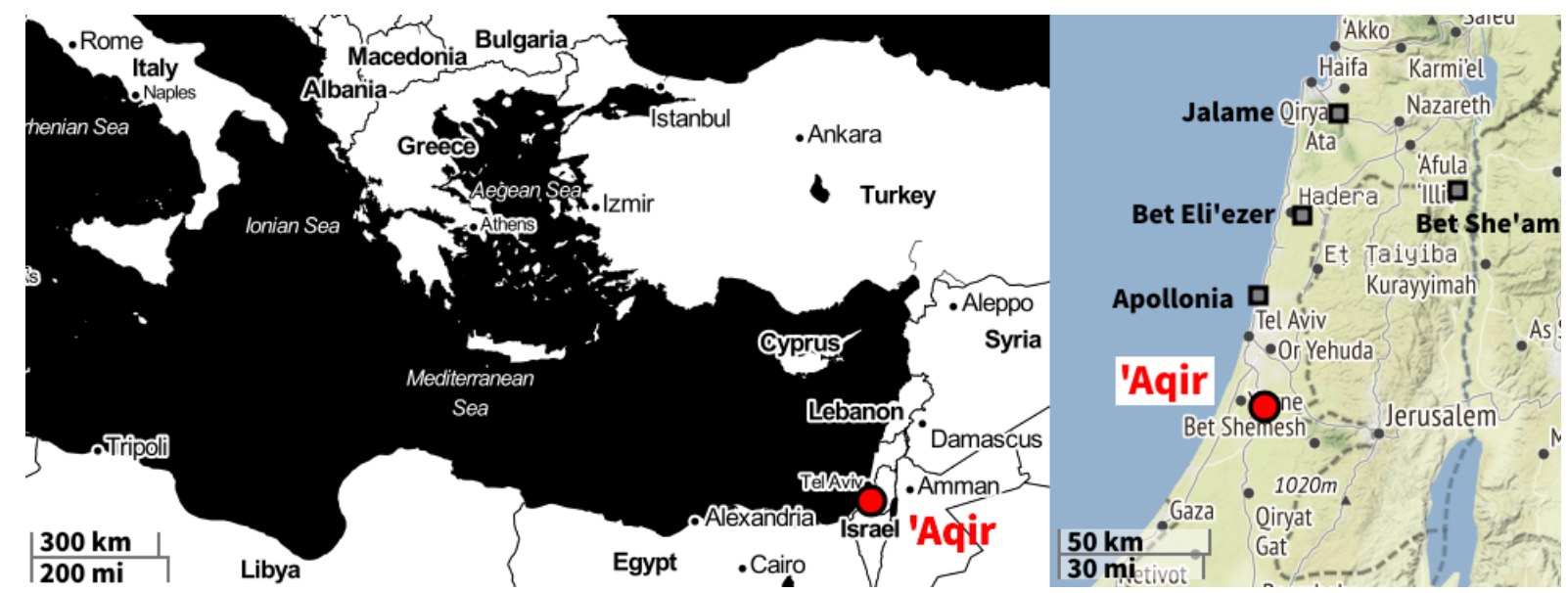

Fig. 1 The location of 'Aqir. Left: 'Aqir in the Eastern Mediterranean Region; Right: 'Aqir and several other ancient glass industrial sites in Israel. Made by Chen Chen using Folium python library (Filipe et al., 2018), base maps from Stamen Toner (left) and Stamen Terrain (right), are built-in to Folium.

Although the site had been damaged by development in the seventeenth century, deposits dating from the late Roman period to the early Islamic period were excavated (Marmelstein, 2016), among which were remains of an ancient glass working installation. The structure has a rectangular shape and was built of ceramic (Marmelstein, 2016, Figs. 9-12). Collapsed ceramic (Gorin-Rosen, 2016, Fig. 21), probably from the roof, filled the structure together with glass lumps and glass working debris (Gorin-Rosen, 2016, Fig. 22). Glass vessel fragments (Gorin-Rosen, 2016, Fig. 24) as well as ceramic sherds of Byzantine jars and a Gaza jar were found closely associated, but not inside the furnace (Marmelstein, 2016, Figs. 6:23-25). Similar debris was also discovered nearby, indicating the possible existence of more glass working installations. No crucibles with glass coatings were retrieved, so it seems probable that the glass was melted in a tank furnace, as appears typical for the region (e.g. Gorin-Rosen, 2000).

The excavated area was fairly small and was damaged in the past, and it seems that the craftsmen took away almost all reusable materials after the workshop was abandoned, so the 
amount of waste is relatively small. Twenty-one samples were selected for analysis, comprising four glass chunks, one moil (the most diagnostic blowing waste; excess glass circling the tip of the blowpipe and knocked off after blowing) as well as twelve fragments of ceramic building material with and without adhering glass. Four glass vessels found close to the furnace were also analysed. All the glass samples are transparent to translucent, decolourised or naturally coloured by iron oxides. Details and illustrations of materials sampled are provided in the appendix.

Two small ceramic samples as well as fragments of all glass samples were mounted in transparent epoxy resin blocks, ground using 600-4000 grit carborundum abrasive and then polished with diamond pastes down to $1 \mu \mathrm{m}$. The polished blocks were vacuum-coated with carbon. Four samples have relatively different compositions from the majority (samples 12, $15, \mathrm{GV}-1$ and GV-4), so repeat samples of these were taken and analysed.

Fragments from seven ceramic samples were prepared into both polished blocks and petrographic thin-sections (Quinn, 2013, p.23-33). A fragment was first ground flat to expose the sample then mounted on a glass microscope slide and ground down to $30 \mu \mathrm{m}$ thickness with carborundum powder.

The thin sections were examined at magnifications of $50-200 \times$ in both plane polarised light (PPL) and between crossed-polars (XP). The thin sections were characterised in terms of their inclusions, matrix and voids. Quantitative modal and textural data was collected by point counting using the 'single intercept' method (Middleton et al., 1985; Quinn, 2013).

Polished samples were examined using a ZEISS EVO 25 scanning electron microscope (SEM), fitted with an Oxford Instruments $\mathrm{X}-\mathrm{Max}^{\mathrm{N}} 80$ Silicon Drift Detector and Aztec Energy Dispersive X-ray Spectrometer (EDS) system. Working conditions were $20.0 \mathrm{kV}$ accelerating voltage, $8.50 \mathrm{~mm}$ working distance, and $100 \mathrm{~s}$ counting time, with a typical yield of c. $3,000,000$ counts on metallic cobalt. Bulk analysis for glass samples was taken at $600 \times$ magnification at 5 different areas, and that for ceramics was typically at $30-150 \times$ magnification for 5 different areas. Oxygen was determined by stoichiometry and results are normalised to $100 \mathrm{wt} \%$.

EDS analysis results for Corning Museum of Glass archaeological reference glasses A, B and $\mathrm{D}$ are presented in Table 1 . For elements with a concentration greater than $5 \%$ the relative errors (RE) were all within 5\% and the relative standard deviations (RSD) were all 
within $2 \%$. For most minor elements $(0.1-5 \%)$ the relative errors were within $10 \%$ of the accepted values. The relative standard deviations of most minor elements were within $10 \%$ but deteriorated as the detection limits of c. $0.1 \%$ were approached. 
Table 1 Accuracy and precision for measurements of glass standards by SEM-EDS

\begin{tabular}{|c|c|c|c|c|c|c|c|c|c|c|c|c|c|c|}
\hline & Content & $\mathrm{Na}_{2} \mathrm{O}$ & $\mathrm{MgO}$ & $\mathrm{Al}_{2} \mathrm{O}_{3}$ & $\mathrm{SiO}_{2}$ & $\mathrm{P}_{2} \mathrm{O}_{5}$ & $\mathrm{SO}_{3}$ & $\mathrm{Cl}$ & $\mathrm{K}_{2} \mathrm{O}$ & $\mathrm{CaO}$ & $\mathrm{TiO}_{2}$ & $\mathrm{MnO}$ & $\mathrm{Fe}_{2} \mathrm{O}_{3}$ & $\mathrm{Sb}_{2} \mathrm{O}_{5}$ \\
\hline \multirow[t]{5}{*}{ Corn A } & Expected wt $\%$ & 14.30 & 2.66 & 1.00 & 66.56 & 0.08 & 0.14 & 0.09 & 2.87 & 5.03 & 0.79 & 1.00 & 1.09 & 1.75 \\
\hline & Mean $(n=3)$ & 14.54 & 2.50 & 0.91 & 67.08 & $<0.1$ & 0.17 & 0.09 & 2.94 & 5.20 & 0.89 & 1.03 & 1.10 & 1.85 \\
\hline & SD & 0.03 & 0.01 & 0.01 & 0.10 & - & 0.04 & 0.02 & 0.03 & 0.05 & 0.07 & 0.06 & 0.01 & 0.12 \\
\hline & Precision=RSD $\%$ & 0.20 & 0.50 & 0.90 & 0.15 & - & 22.09 & 18.21 & 0.89 & 1.05 & 8.00 & 6.19 & 0.85 & 6.26 \\
\hline & Accuracy=RE $\%$ & 1.70 & -6.14 & -9.00 & 0.79 & & 19.05 & 3.70 & 2.56 & 3.31 & 12.66 & 3.00 & 1.22 & 5.52 \\
\hline \multirow[t]{5}{*}{ Corn B } & Expected wt\% & 17.00 & 1.03 & 4.36 & 61.55 & 0.82 & 0.49 & 0.16 & 1.00 & 8.56 & 0.09 & 0.25 & 0.34 & 0.46 \\
\hline & Mean $(n=3)$ & 17.19 & 1.02 & 4.16 & 61.36 & 0.91 & 0.60 & 0.16 & 1.11 & 8.88 & 0.14 & 0.24 & 0.36 & 0.49 \\
\hline & $\mathrm{SD}$ & 0.06 & 0.03 & 0.07 & 0.01 & 0.02 & 0.01 & 0.00 & 0.01 & 0.08 & 0.03 & 0.02 & 0.01 & 0.04 \\
\hline & Precision=RSD $\%$ & 0.36 & 2.56 & 1.67 & 0.02 & 2.69 & 2.36 & 2.89 & 0.74 & 0.93 & 23.72 & 8.68 & 3.50 & 7.82 \\
\hline & Accuracy=RE $\%$ & 1.12 & -0.65 & -4.66 & -0.31 & 10.98 & 22.45 & 2.08 & 11.00 & 3.70 & 61.05 & -5.33 & 4.90 & 7.25 \\
\hline \multirow[t]{5}{*}{ Corn D } & Expected wt\% & 1.20 & 3.94 & 5.30 & 55.24 & 3.93 & 0.23 & 0.16 & 11.30 & 14.80 & 0.38 & 0.55 & 0.52 & 0.97 \\
\hline & Mean $(n=3)$ & 1.34 & 3.87 & 5.09 & 54.87 & 4.22 & 0.22 & 0.17 & 11.58 & 15.12 & 0.39 & 0.55 & 0.53 & 1.13 \\
\hline & SD & 0.06 & 0.02 & 0.09 & 0.03 & 0.05 & 0.01 & 0.00 & 0.06 & 0.04 & 0.05 & 0.04 & 0.03 & 0.03 \\
\hline & Precision=RSD $\%$ & 4.27 & 0.63 & 1.77 & 0.06 & 1.17 & 4.22 & 0.00 & 0.53 & 0.29 & 11.80 & 6.80 & 5.44 & 2.32 \\
\hline & Accuracy=RE $\%$ & 11.67 & -1.78 & -3.90 & -0.66 & 7.29 & -2.90 & 6.25 & 2.45 & 2.16 & 3.51 & 0.00 & 1.28 & 16.84 \\
\hline
\end{tabular}

$\mathrm{SD}=$ standard deviation, $\mathrm{RSD}=$ relative standard deviation, $\mathrm{RE}=$ relative error = (Measurement value - True value)/True value. Errors which exceed our preferred limit of $10 \%$ are shown in bold, and typically occur as values approach $0.1 \%$ element. Expected values are mainly from Brill (1999) with additional information from Adlington (2017). 
Table 2 SEM-EDS analyses of ceramic samples from 'Aqir, normalised to $100 \%$

\begin{tabular}{|c|c|c|c|c|c|c|c|c|c|c|c|c|c|}
\hline Sample & Material Type & $\mathrm{Na}_{2} \mathrm{O}$ & $\mathrm{MgO}$ & $\mathrm{Al}_{2} \mathrm{O}_{3}$ & $\mathrm{SiO}_{2}$ & $\mathrm{P}_{2} \mathrm{O}_{5}$ & $\mathrm{SO}_{3}$ & $\mathrm{Cl}$ & $\mathrm{K}_{2} \mathrm{O}$ & $\mathrm{CaO}$ & $\mathrm{TiO}_{2}$ & $\mathrm{MnO}$ & $\mathrm{Fe}_{2} \mathrm{O}_{3}$ \\
\hline 1 & Clay ceramic & 0.8 & 1.5 & 9.5 & 74.3 & $<0.1$ & 0.1 & 0.2 & 2.3 & 4.9 & 1.0 & $<0.1$ & 5.4 \\
\hline 2 & Clay ceramic & 1.2 & 1.9 & 10.8 & 65.6 & $<0.1$ & 0.4 & 1.1 & 2.3 & 9.9 & 1.3 & $<0.1$ & 5.7 \\
\hline 4 & Clay ceramic & 0.6 & 1.0 & 10.0 & 78.1 & $<0.1$ & $<0.1$ & $<0.1$ & 1.5 & 2.9 & 0.9 & $<0.1$ & 5.1 \\
\hline 5-black area & Clay ceramic & 0.7 & 1.1 & 8.5 & 77.3 & $<0.1$ & 0.2 & 0.1 & 2.3 & 3.9 & 0.9 & $<0.1$ & 5.0 \\
\hline 5b-vitrified & Vitrified surface & 3.5 & 2.2 & 8.2 & 62.0 & 0.3 & $<0.1$ & $<0.1$ & 7.3 & 9.6 & 0.9 & 0.2 & 5.9 \\
\hline 7 & Clay ceramic & 0.5 & 1.2 & 8.1 & 79.7 & $<0.1$ & 0.1 & 0.2 & 1.4 & 3.8 & 0.8 & $<0.1$ & 4.1 \\
\hline 7-vitrified & Vitrified surface & 3.2 & 1.9 & 7.1 & 69.8 & 0.7 & $<0.1$ & $<0.1$ & 8.0 & 5.1 & 0.7 & $<0.1$ & 3.7 \\
\hline $8 \mathrm{c}$ & Lime-rich & 1.3 & 3.0 & 3.6 & 55.7 & 0.3 & 0.3 & 0.1 & 0.3 & 33.2 & 0.3 & $<0.1$ & 1.8 \\
\hline 10 & Clay ceramic & 0.4 & 0.8 & 8.6 & 82.2 & $<0.1$ & 0.1 & 0.2 & 1.1 & 1.5 & 0.6 & $<0.1$ & 4.6 \\
\hline 10-vitrified & Vitrified surface & 2.3 & 1.6 & 8.2 & 69.2 & 0.5 & $<0.1$ & $<0.1$ & 7.4 & 7.1 & 0.5 & $<0.1$ & 3.1 \\
\hline 14-Area C & Glass on lime-rich & 4.9 & 0.8 & 2.6 & 72.7 & $<0.1$ & 0.2 & 0.2 & 1.2 & 15.6 & 0.2 & $<0.1$ & 1.8 \\
\hline 14-Area D & Glass on lime-rich & 8.1 & 0.7 & 2.7 & 65.1 & 0.1 & 0.2 & 0.5 & 1.0 & 20.8 & $<0.1$ & $<0.1$ & 0.9 \\
\hline 14-Area E & Clay ceramic & 2.8 & 0.7 & 7.2 & 77.7 & 0.6 & 0.2 & 0.4 & 2.3 & 3.5 & 0.5 & $<0.1$ & 4.0 \\
\hline $16 \mathrm{c}$ & Lime-rich & 1.5 & 3.7 & 5.1 & 45.6 & 1.8 & 0.4 & 0.1 & 0.3 & 39.2 & 0.3 & 0.3 & 1.9 \\
\hline
\end{tabular}

Chemical compositions are given in wt $\%$. Mean of five area analyses, except sample 2 (average of two) and sample 3 (average of two). The letter 'c' denotes the ceramic part of a composite glass-ceramic sample. The figures in italic are close to the limit of detection and have a higher uncertainty. 
Table 3 SEM-EDS analyses of glass samples from 'Aqir, normalised to $100 \%$

\begin{tabular}{|c|c|c|c|c|c|c|c|c|c|c|c|c|c|c|}
\hline Sample & Type & $\mathrm{Na}_{2} \mathrm{O}$ & $\mathrm{MgO}$ & $\mathrm{Al}_{2} \mathrm{O}_{3}$ & $\mathrm{SiO}_{2}$ & $\mathrm{P}_{2} \mathrm{O}_{5}$ & $\mathrm{SO}_{3}$ & $\mathrm{Cl}$ & $\mathrm{K}_{2} \mathrm{O}$ & $\mathrm{CaO}$ & $\mathrm{TiO}_{2}$ & $\mathrm{MnO}$ & $\mathrm{Fe}_{2} \mathrm{O}_{3}$ & $\mathrm{Sb}_{2} \mathrm{O}_{5}$ \\
\hline \multicolumn{15}{|c|}{ Glassworking debris } \\
\hline $8 \mathrm{~g}$ & glass with ceramic & 13.0 & 0.64 & 3.1 & 71.3 & $<0.1$ & $<0.1$ & 0.74 & 0.60 & 10.0 & 0.1 & $<0.1$ & 0.53 & $<0.3$ \\
\hline 11 & moil & 13.8 & 0.69 & 3.1 & 70.6 & $<0.1$ & 0.1 & 0.74 & 0.93 & 9.6 & $<0.1$ & $<0.1$ & 0.50 & $<0.3$ \\
\hline $12 \_1$ & lump & 14.8 & 0.73 & 2.9 & 64.6 & 0.2 & 0.1 & 0.58 & 0.71 & 14.7 & 0.1 & $<0.1$ & 0.60 & $<0.3$ \\
\hline $15 \_1$ & lump & 9.7 & 0.71 & 3.1 & 72.4 & $<0.1$ & $<0.1$ & 0.36 & 0.61 & 12.3 & 0.1 & $<0.1$ & 0.67 & $<0.3$ \\
\hline $15 \_2$ & lump & 11.8 & 0.66 & 3.1 & 72.1 & $<0.1$ & $<0.1$ & 0.53 & 0.62 & 10.6 & 0.1 & $<0.1$ & 0.55 & $<0.3$ \\
\hline $16 \mathrm{~g}$ & glass with ceramic & 14.3 & 0.67 & 3.1 & 70.7 & $<0.1$ & 0.2 & 0.73 & 0.63 & 9.3 & $<0.1$ & $<0.1$ & 0.47 & $<0.3$ \\
\hline 17 & lump & 15.2 & 0.69 & 3.1 & 66.8 & 0.2 & $<0.1$ & 0.68 & 0.99 & 11.7 & $<0.1$ & $<0.1$ & 0.65 & $<0.3$ \\
\hline GV-2 & vessel & 19.0 & 0.56 & 2.4 & 66.4 & $<0.1$ & 0.3 & 1.09 & 0.59 & 8.0 & $<0.1$ & 0.99 & 0.74 & $<0.3$ \\
\hline GV-3 & vessel & 14.1 & 0.66 & 2.6 & 70.3 & $<0.1$ & 0.2 & 0.73 & 1.10 & 8.6 & $<0.1$ & 1.30 & 0.54 & $<0.3$ \\
\hline GV-4_1 & vessel & 13.9 & 0.53 & 2.5 & 70.7 & $<0.1$ & $<0.1$ & 1.08 & 0.25 & 9.8 & 0.3 & $<0.1$ & 0.96 & $<0.3$ \\
\hline GV-4_2 & vessel & 14.1 & 0.55 & 2.5 & 70.7 & $<0.1$ & 0.1 & 1.04 & 0.28 & 9.6 & 0.3 & $<0.1$ & 0.97 & $<0.3$ \\
\hline
\end{tabular}

Chemical compositions are given in wt $\%$. Mean of 5 values, sample_1 and 2 means two pieces of the same sample. The letter ' $\mathrm{g}$ ' denotes the glass part of a composite glass-ceramic sample. The figures in italic are close to the limit of detection and have a higher uncertainty. 


\section{Results}

\subsection{Furnace materials}

The structural furnace materials are mostly black to dark brown, some are brownish-red (samples 3 and 5), some with black glassy surface layers (samples 5-black part, 7 and 10). They are seen to comprise a quartz-rich fabric with c. $30 \%$ inclusions, predominantly subangular to sub-rounded fine quartz sand grains $(<0.90 \mathrm{~mm}$, mode $=0.19 \mathrm{~mm})$ with rare feldspar (Fig. 2, in some cases molten to pools of glass with included acicular crystals, probably mullite) and chert. Rare wollastonite and secondary calcite are also present. The matrices, making up about $50 \%$ of a section, are typically isotropic; however, the red area of sample 5 is slightly birefringent in thin section. The remaining c. $20 \%$ comprises voids, some are very coarse bloating pores $(>100 \mu \mathrm{m}$; Freestone and Tite, 1986). The quartz sand grains are well sorted and do not grade into a fine fraction; they are assumed to have been added to the clay.

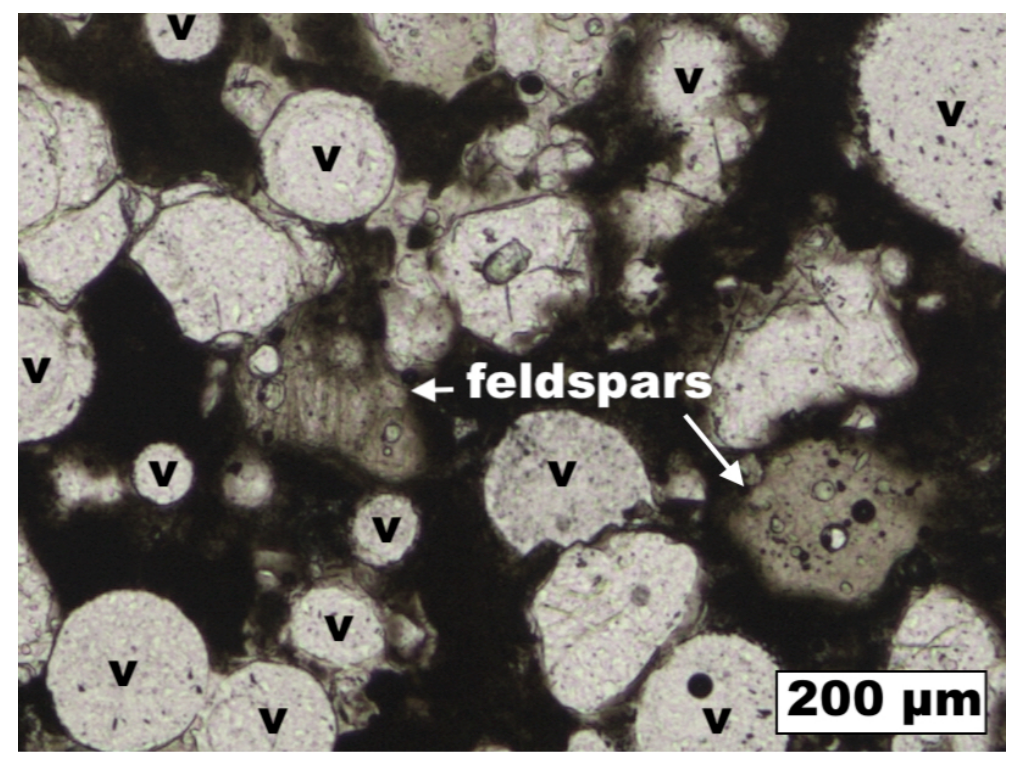

Fig. 2. Thin-section photomicrograph of ceramic sample 6 in plane polarised light (PPL) showing two molten feldspars, the light particles are quartz; spheroidal gas bubbles are also visible (voids labelled with ' $v$ ').

The bulk compositions of the clay ceramic (samples 1-7 and 10) are given in Table 2; they are silica-rich and contain $8-11 \% \mathrm{Al}_{2} \mathrm{O}_{3}$ and $3-5 \% \mathrm{Fe}_{2} \mathrm{O}_{3}$, with $\mathrm{CaO}$ typically below 
5\%. Their $\mathrm{Fe}_{2} \mathrm{O}_{3} / \mathrm{Al}_{2} \mathrm{O}_{3}$ and $\mathrm{Fe}_{2} \mathrm{O}_{3} / \mathrm{TiO}_{2}$ ratios are c. 0.5 and 5 respectively, which are close to those of typical alluvial clay (Kamber et al., 2005). These materials appear to represent an alluvial-type low-refractory clay with a sand temper and are interpreted as the remains of the furnace bricks.

Only a single sample (13c, Table 2; labelled soda-rich clay in Fig. 3) appears to unambiguously represent the result of contamination of furnace brick by soda-lime-silica glass, with elevated soda but low in the ash constituents, potash and phosphate.

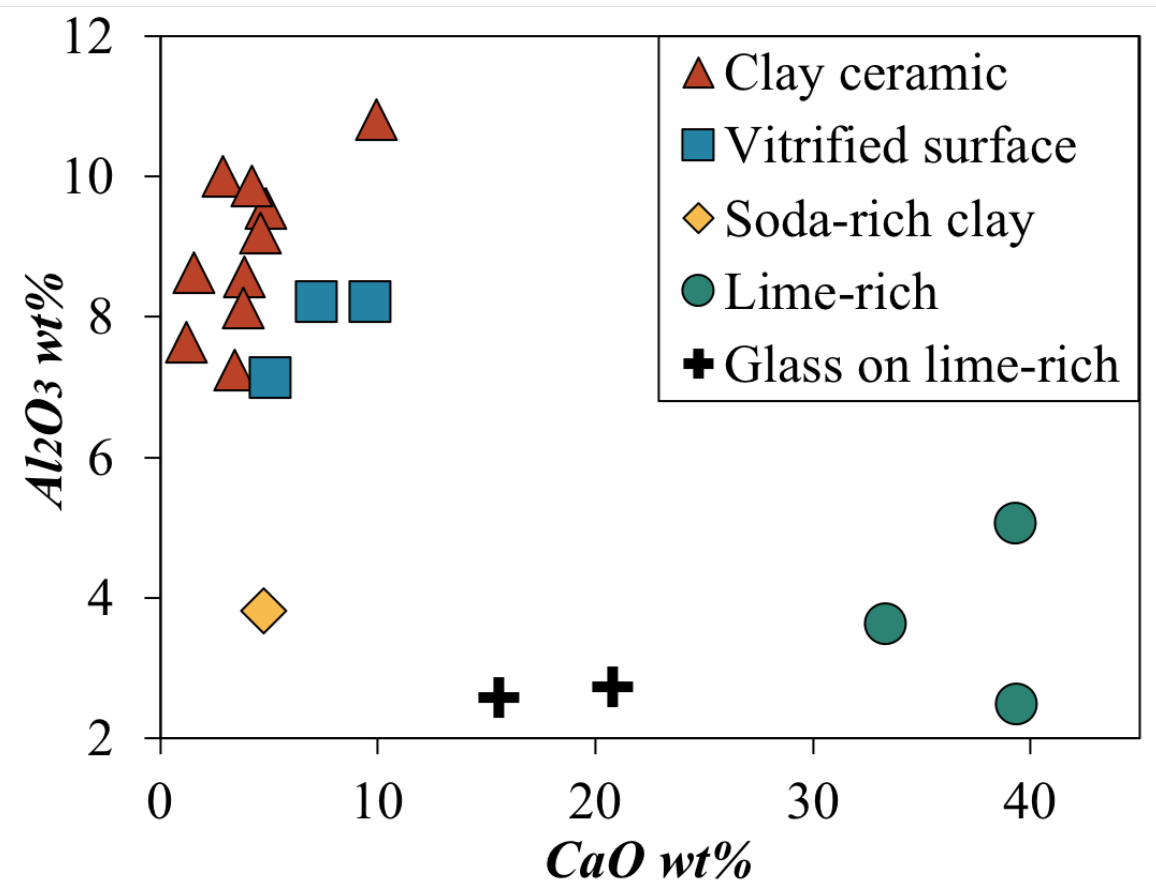

Fig. 3 Bivariate plot of lime and alumina contents of furnace materials.

The ceramics frequently comprise complex samples with areas of different composition. The compositional relationships between them are summarised in Fig. 3. In addition to the clay-based ceramics described above we identify several types of material. Relatively smooth glaze-like surface layers, which are rich in $\mathrm{K}_{2} \mathrm{O}$, occur on samples 5, 7 and 10 (Table 2). They have elevated $\mathrm{K}_{2} \mathrm{O}(7-8 \%), \mathrm{Na}_{2} \mathrm{O}(2.0-3.5 \%)$ and $\mathrm{P}_{2} \mathrm{O}_{5}(0.3-0.7 \%)$ and are also slightly higher in $\mathrm{CaO}$ than the respective ceramic bodies (Fig. 3), suggesting that potash-rich fuel ash and vapour (and possibly sodium-rich vapour from the glass) had reacted with and fluxed the clay (Paynter, 2008; Rehren and Perini, 2005). These are therefore bricks from the furnace wall or roof above the tank which held the glass, rather than samples which were in contact with the glass itself. 
A second group of ceramic materials are rich in lime. For example, Sample 14 is a complex fragment which comprises both clay and lime-rich areas, as shown in Fig. 4, where area $\mathrm{E}$ is the typical clay ceramic fabric described above (Fig. 4vi). Area B is essentially lime with low silica, it contains a few quartz grains which show reaction rims with the matrix (Fig. 4iii). Area $\mathrm{A}$ consists of c. $51 \% \mathrm{SiO}_{2}$ and $39 \% \mathrm{CaO}$ (Table 2) and contains sparse quartz grains which again show reaction rims with the calcium silicate matrix (Fig. 4iv). Area $\mathrm{C}$ has sparse quartz in a glassy matrix, and contains $4.9 \% \mathrm{Na}_{2} \mathrm{O}$ and $15.6 \% \mathrm{CaO}$; it appears to be the product of a reaction between soda-lime-silica glass and sand-tempered lime. Area D is glass containing $8.1 \% \mathrm{Na}_{2} \mathrm{O}$ and $20.8 \% \mathrm{CaO}$; it contains extensive wollastonite $\left(\mathrm{CaSiO}_{3}\right)$ crystals (Fig. 4v) and appears to represent soda-lime-silica glass which has dissolved significant amounts of lime.

Other lime-rich ceramics were found as part of composite samples 8 and 16. They are relatively thin lime-rich layers adhering to the pieces of the typical soda-lime-silica glass associated with the furnace. They comprise complex materials with c. $39 \% \mathrm{CaO}$ and $50 \%$ $\mathrm{SiO}_{2}$ (samples 8c and 16c, Table 2). They include areas of glass and a neo-formed crystalline phase with a composition (c. $4 \% \mathrm{Na}_{2} \mathrm{O}, 6 \% \mathrm{MgO}, 10 \% \mathrm{Al}_{2} \mathrm{O}_{3}, 42 \% \mathrm{SiO}_{2},<0.1 \% \mathrm{~K}_{2} \mathrm{O}, 33 \%$ $\mathrm{CaO}$ and $2.5 \% \quad \mathrm{Fe}_{2} \mathrm{O}_{3}$ ) which corresponds closely to the melilite group mineral alumoåkermanite (Weidenmann et al., 2009) in a matrix consisting of domains of a fibrous silica-rich phase with interstitial voids which sometimes contain calcareous material (Fig. 5). Morphologically these domains closely resemble the texture of the mineral larnite $\left(\mathrm{Ca}_{2} \mathrm{SiO}_{4}\right)$, formed during combustion metamorphism of oil shale; compare Fig. 5 of this paper with Gross, 2016 (pp 67), Sokol et al., 2019 (figures 7 \& 8) and Fukuda and Maki, 1989 (Fig. 1). As one of the reactive phases in portland cement, larnite is well understood to be unstable and breaks down in water (e.g. Sokol et al., 2019). The presence of larnite pseudomorphs in high temperature archaeological calc-silicates exposed to post-depositional processes is therefore to be expected. The inferred loss of $\mathrm{CaO}$ during the alteration process suggests that our measurements of the compositions of these layers (Table 2) are likely to be low in $\mathrm{CaO}$ relative to the pristine materials. 


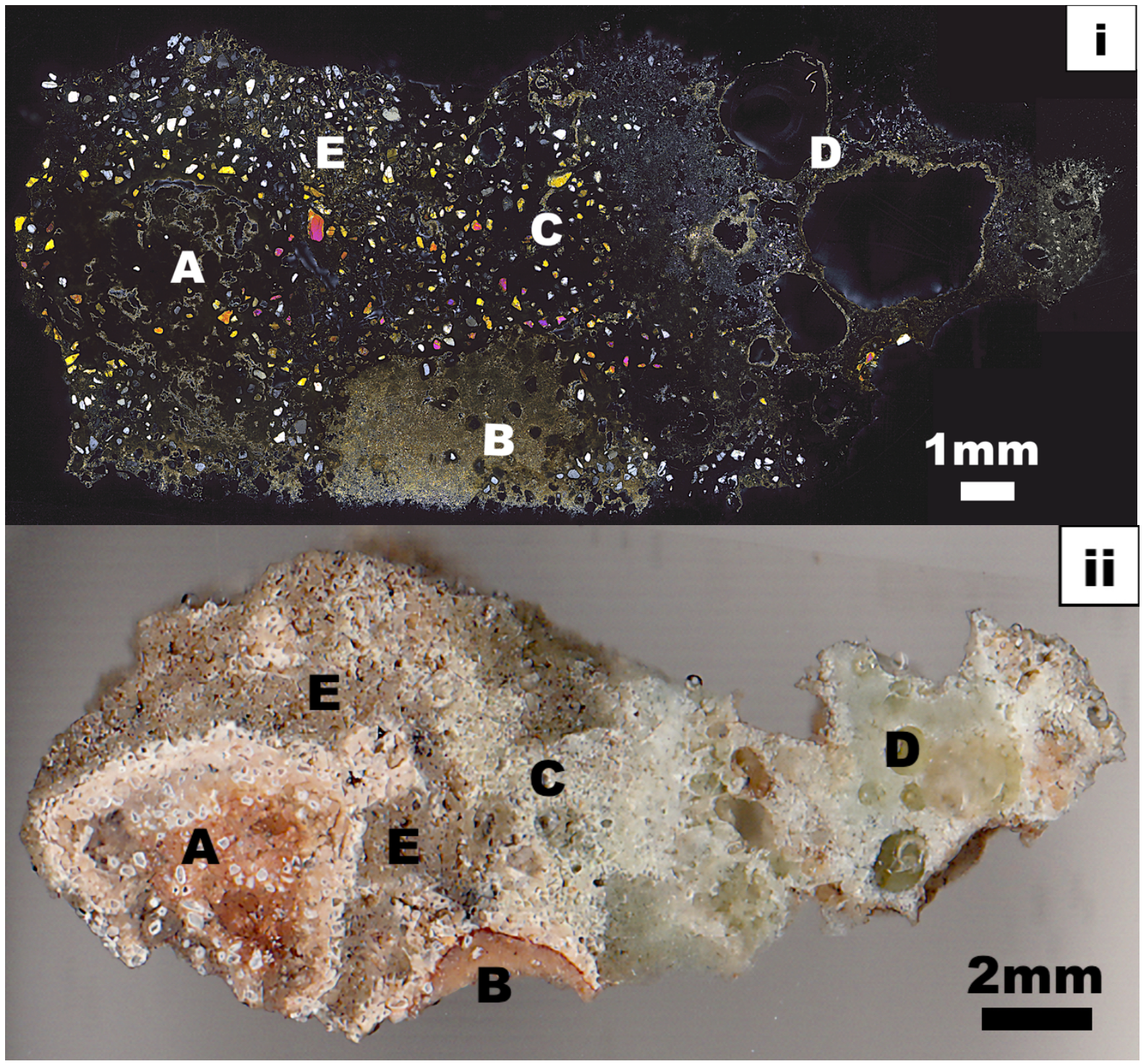




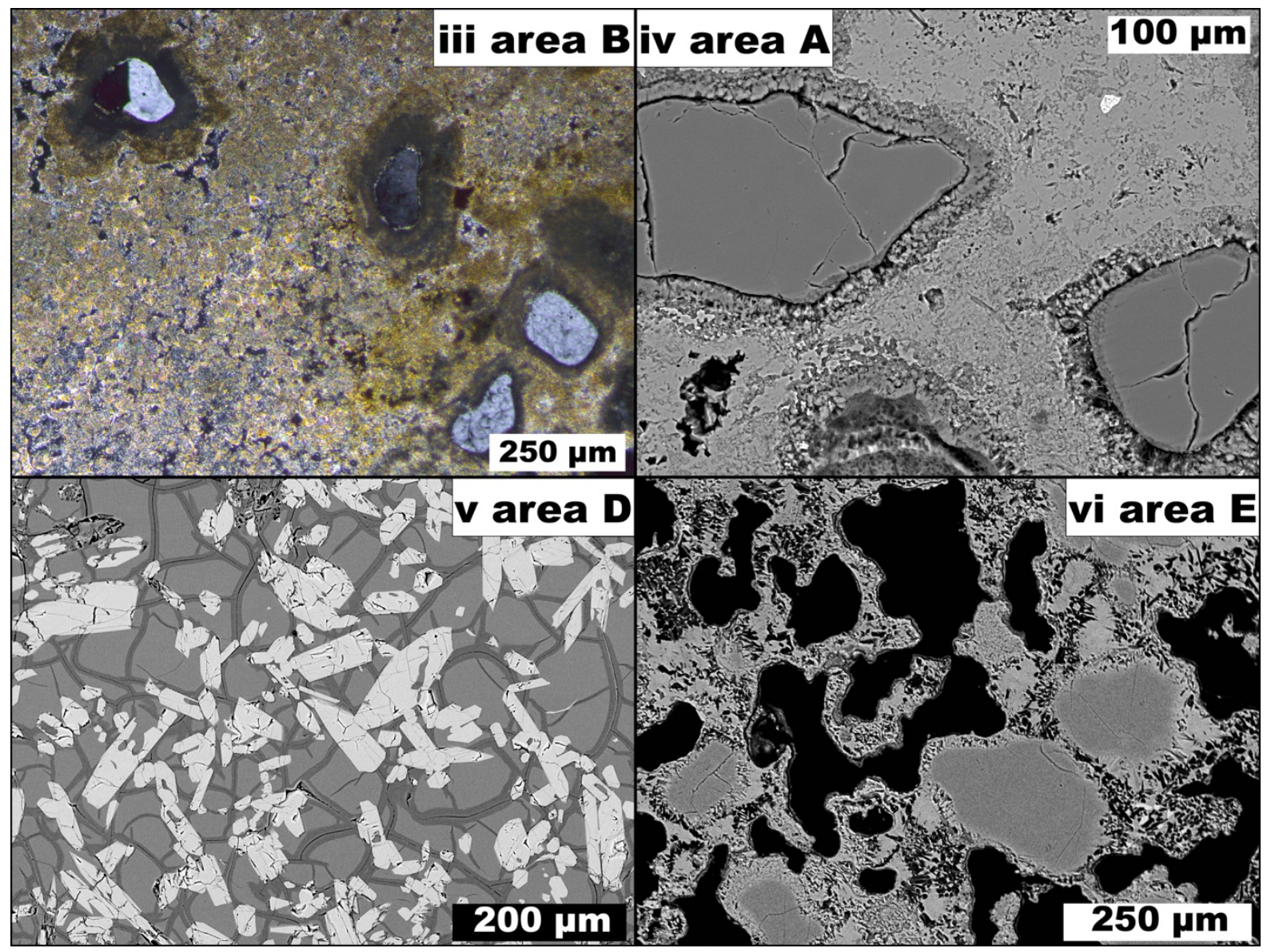

Fig. 4 Sample 14. i: thin section photomicrograph (XP). A \& B: calcareous materials, C: glass penetrated into ceramic, D: wollastonite plus glass, E: clay ceramic; ii: polished block in ordinary light (different fragment of sample 14); iii: thin section photomicrograph (XP) of area $\mathrm{B}$, showing rare grey quartz crystals with dark-brown reaction rims in a yellow-brown calcareous matrix; iv-vi: backscattered electron (BSE) images of different areas. iv: area A, showing grey quartz sand inclusions with reaction rims in a calcareous matrix, growth of secondary calcite crystals is observed on its bottom left; v: area D, showing light-grey blocky wollastonite crystals formed in a glassy matrix; vi: area $\mathrm{E}$, showing grey quartz sand inclusions in porous matrix, the black areas are voids. 


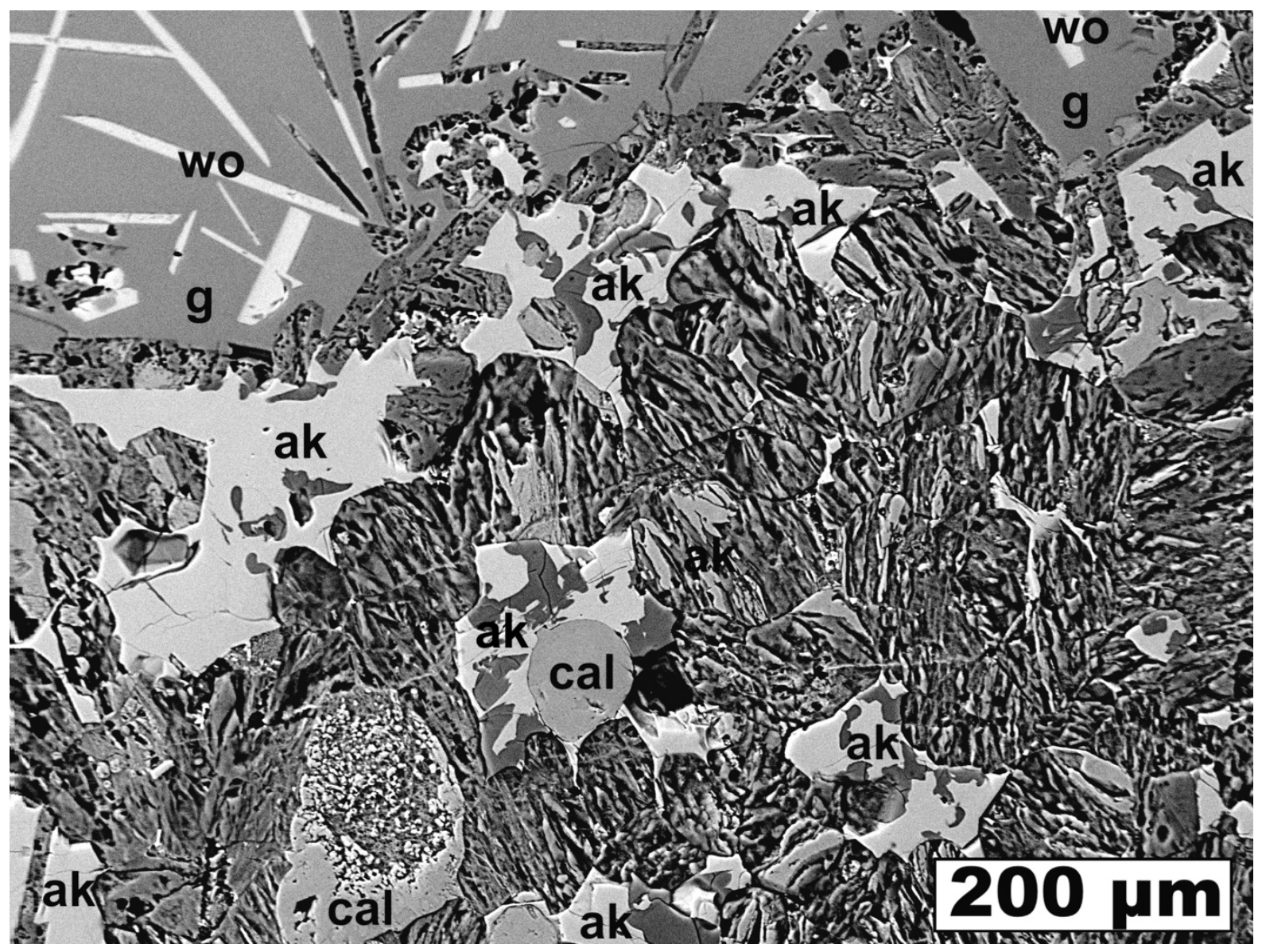

Fig. 5 BSE image of sample 8c. The flat dark-grey phases at the top are high-Al, Fe soda-lime-silica glass (g) with light-grey acicular wollastonite (wo) crystals inside, the mid-grey rounded phases are calcite (cal), and the light-grey irregular areas are alumoåkermanite (ak). The fibrous matrix comprises domains consisting mainly of crystallites of a silica phase with interstitial voids; these are interpreted as pseudomorphs after larnite (see text).

\subsection{Glass}

The compositions of the glass samples are given in Table 2. For those that have been sampled and analysed twice $(12,15, \mathrm{GV}-1$ and GV-4), a '_1' or ' 2 ' has been added after the sample names to distinguish the two analyses. The glass samples are all low-magnesium, low-potassium soda-lime-silica (natron) type.

Most of the glassworking remains (samples 8, 9, 13, 16 and the moil, sample 11) have $\mathrm{Na}_{2} \mathrm{O}$ in the range $12-15 \%, \mathrm{CaO} 8-11 \%$ and $\mathrm{Al}_{2} \mathrm{O}_{3}$ around $3 \%$ with $\mathrm{TiO}_{2}$ close to the detection limit. These samples match in many respects the glass analysed from the primary 
production furnaces at Apollonia (Freestone et al., 2000; Tal et al., 2004; Freestone et al., 2008; summarised in Freestone, 2020). However, glass with $\mathrm{CaO}$ greater than $11 \%$ has not been analysed from the Apollonia furnaces, but samples 12,15 and 17 have lime ranging from 11 to $15 \%$. Furthermore, while the average lime content of Apollonia raw glass is 8$8.5 \%$ (Freestone, 2020), the mean lime content of the present samples is $10.7 \%$ (median value is $9.9 \%$ ). In addition, both analysed pieces of sample 15 resemble Apollonia-type glass but they have low $\mathrm{Na}_{2} \mathrm{O}$ and $\mathrm{Cl}$ and are zoned with respect to these components.

The number of primary glassmaking centres at any period was limited, on the basis of the production sites which have been excavated to date and the compositional groups which have been identified (Freestone et al., 2000; Gorin-Rosen, 2000; Foy et al., 2003; Schibille et al., 2017). In contrast to the glass waste from the furnace, none of the four glass vessels are of the Apollonia type. GV-1 has high soda and low alumina and was decolourised using antimony (Table 3). It is typical of Roman-Sb glass of the first-fourth centuries, probably originating in Egypt (Gliozzo 2017; Schibille et al., 2017; Barfod et al., 2020). GV-2 which contains c. 1\% $\mathrm{MnO}$ is higher in $\mathrm{Na}_{2} \mathrm{O}(19.0 \%)$ than typical Roman-Mn type of the 1st-4th centuries CE (up to $17.5 \%$ according to the data of Silvestri et al., 2008) but of the recognised glass groups (Freestone, 2021), this appears to be the best fit and the glass is similar to that of Jalame (Brill, 1988). It is unlikely to be one of the later 5-6th century groups: $\mathrm{Al}_{2} \mathrm{O}_{3}$ is too high for Foy série 3.2 and $\mathrm{MgO}$ and $\mathrm{Fe}_{2} \mathrm{O}_{3}$ are too low for HIMT or Foy 2.1. GV-3 is part of a beaker with solid base, a well-known form dating back to the fourth century CE (Gorin-Rosen, 2016, Fig. 24:6), and its composition is also typical of Roman Mn-decolourised glass of the period and region (e.g. Brill, 1988). GV-4 has high $\mathrm{TiO}_{2}$, indicating a likely Egyptian origin, and accords with Egypt II type (Phelps et al., 2016) dating to the late-8th to 9th centuries (Schibille et al., 2019). This piece, which was sampled and analysed twice, is somewhat anomalous with respect to the rest of the assemblage but other characteristics, particularly the low $\mathrm{K}_{2} \mathrm{O}$ (Table 3), match Egypt II very well.

\section{Discussion}

\subsection{Furnace, fuel and operational temperature}

The structure of the furnace was built using bricks made from an alluvial-type clay, with a sand temper. The glazed surface layers of the bricks from the furnace superstructure show 
elevated potash, soda, phosphorus and lime, suggesting contamination from potash-rich fuel ash (Paynter, 2008; Rehren and Perini, 2005). In addition to the available plants and woods, the use of olive-pressing residue or 'pomace' (Rowan, 2015) as a fuel in glass furnaces was suggested by Gorin-Rosen (2000) in Byzantine Bet She'an, Israel and by Barfod et al. (2018) in Byzantine and early Islamic Jerash, Jordan, and the latter authors note that the ash of olive residue is especially high in $\mathrm{K}_{2} \mathrm{O}$. The vitrified layers are contaminated by soda as well as potash and while this may represent vapour from the glass, pottery surfaces glazed by sodarich fuel vapour have been reported by Freestone et al. (2001) at Deir 'Ain 'Abata, Jordan and the fuel must be considered a possible soda source.

Although one ceramic sample (13c; Table 3) shows evidence of contamination of the clay furnace brick by glass, most of the ceramic samples which show interaction with the sodalime-silica glass show elevated lime. Lime appears to have present as a mortar containing varying amounts of a sand aggregate, similar to the sand used to temper the brick clay. There appears to have been extensive high-temperature interaction between the lime and the quartz and where present, the quartz grains have well developed reaction rims (Fig. 4iv). In two examples, samples $8 \mathrm{c}$ and $16 \mathrm{c}$, the reaction between quartz sand grains and lime matrix appears to have gone to completion, so that no relict sand grains are present and a complex phase assemblage has resulted. This may have been accelerated due to contamination by minor amounts of glass (Fig. 5); Sample 14 (Area A) where quartz grains may be observed, is lower in $\mathrm{Na}_{2} \mathrm{O}$ than samples $8 \mathrm{c}$ and $16 \mathrm{c}$, which are otherwise similar in composition.

Hunault et al. (2017) estimate the working temperatures of soda-lime-silica glass to be in the range $750-1050^{\circ} \mathrm{C}$. Experiments with a wood-fired pot furnace by Taylor and Hill (2008) indicate maximum temperatures in the melting chamber of around $1175^{\circ} \mathrm{C}$, but typically in the range $1100-1150^{\circ} \mathrm{C}$. The molten feldspars identified in both thin-section microscopy (Fig. 2) and SEM analysis are consistent with these figures, as the minimum melting temperature in the alkali feldspar phase diagram is c. $1080^{\circ} \mathrm{C}$ (Roedder, 1959) suggesting a temperature higher than this. In addition, the clay matrix of sample 10, which does not appear to be significantly contaminated by fluxes, shows continuous vitrification with very coarse bloating pores $(>100 \mu \mathrm{m})$, indicating a temperature over $1100^{\circ} \mathrm{C}$ for most clay types (Freestone and Tite, 1986; Tite, 1999). It should be noted that the temperatures inside the ceramics were zoned, as might be expected of furnace wall, as the matrix of the red area of 
sample 5 is slightly birefringent in thin section suggesting a temperature $<850^{\circ} \mathrm{C}$ (Quinn, 2013, pp. 191).

\subsection{Compositional variation of glass}

While both analysed pieces of sample 15 match Apollonia-type glass, they show zoning with respect $\mathrm{Na}_{2} \mathrm{O}$ and $\mathrm{Cl}$, which are low, suggesting that this sample lost sodium mainly in the form of sodium chloride $(\mathrm{NaCl})$ due to vaporisation during prolonged heating in high temperature (Gerth et al., 1998).

The lime contents among most 'Aqir glass production materials are higher than the raw glass chunks produced in Apollonia, and slightly higher than those of the Islamic period Levantine natron glass assemblage from Raqqa, Syria (Henderson et al., 2004; Henderson et al., 2005), which has been noted (Phelps et al., 2016) to be characterised by relatively high $\mathrm{CaO}$ concentrations (typically $8-10 \%$ ). This observation of elevated $\mathrm{CaO}$ is only marginally affected by the minor deviation of the present analyses from the Corning standards of $0.2-$ $0.3 \%$ (Table 1).

Fig. 6 illustrates a strong correlation of $\mathrm{Fe}_{2} \mathrm{O}_{3}$ and $\mathrm{CaO}$ contents among eight 'Aqir glass waste samples $\left(\mathrm{R}^{2}=0.98\right)$. Sample 12 has been neglected, as both analyses lie off the trend defined by the other glasses; this sample has other characteristics, such as slightly elevated $\mathrm{Na}_{2} \mathrm{O}, \mathrm{MgO}$, and possibly $\mathrm{P}_{2} \mathrm{O}_{5}$ which suggest it may have been additionally contaminated by

the fuel (Table 3). The strong correlation suggests that the additional iron oxide and lime in the majority of the samples have a common origin and that an explanation for the elevated $\mathrm{CaO}$ should take this into account. This $\mathrm{Fe}_{2} \mathrm{O}_{3}-\mathrm{CaO}$ relationship does not occur among Apollonia raw glass chunks (Freestone et al., 2000; Tal et al., 2004; Freestone et al., 2008; Abd-Allah, 2010) and most other published Apollonia type glass products (e.g. Al-Bashaireh et al., 2016b; Ali and Abd-Allah, 2015; Barfod et al., 2018; El-Khouri, 2014; Phelps et al., 2016; Rehren et al., 2010; Tal et al., 2008), suggesting that a contamination was introduced into the 'Aqir glasses during the glassworking campaign, rather than inherited from the raw glass. 


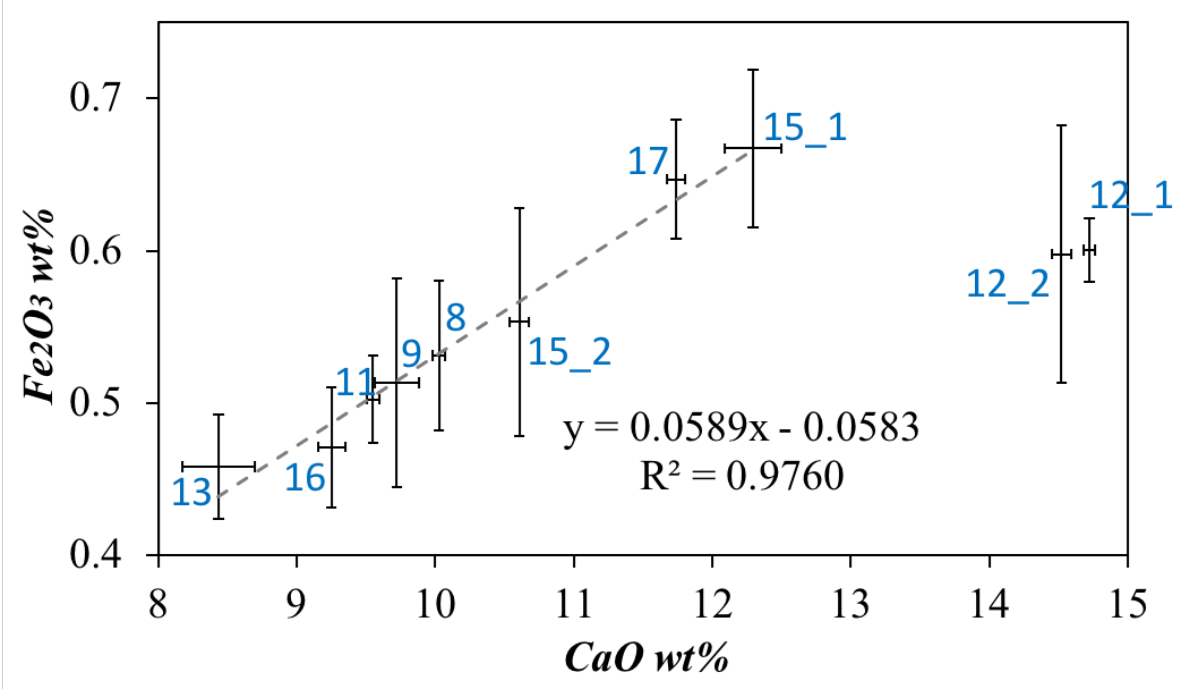

Fig. 6 Bivariate plot of iron oxide and lime content with error bars (error $=$ standard deviation of 5 analysis) among glass production materials, $12 \_1$ and $12 \_2$ are outliers.

Six of the samples analysed $(8,9,12,13,15,16)$ are debris containing both glass and ceramic, suggesting that they came from the walls or floors of glass furnaces. Among them, the ceramic areas of samples 8 and 16 are notably high in $\mathrm{CaO}(33.2 \%$ and $39.2 \%$ respectively). Areas $\mathrm{A}$ and $\mathrm{B}$ of complex sample 14 are also high in $\mathrm{CaO}(39.2 \%$ and 89.4\% respectively). Sample 13 is not as high in lime in its ceramic area $(4.8 \% \mathrm{CaO})$, and the $\mathrm{CaO}$ concentration in the attached glass is the lowest among the eight samples (8.4\%) and within the typical Apollonia range (7-9\%). These observations suggest that the calcareous structural materials (mortar or plaster) of the furnaces are likely the source of additional lime. The wollastonite-rich glass in sample 14 (Area D; Fig. 4v) has a $\mathrm{Na}_{2} \mathrm{O}$ content of c. $8 \%$ along with c. $21 \% \mathrm{CaO}$; the high $\mathrm{Na}_{2} \mathrm{O}$ indicates that the source of the silica was mostly the sodalime-silica glass, rather than quartz sand. Thus, we may conclude that these calcareous materials were in contact with the glass during the melting process. They may have been used to cement the gaps between the mudbricks or to line the furnace as a parting layer (a calciumrich coating allowing easy release of glass after working, Merkel and Rehren, 2007). While it is possible that the lime might be present in the furnace structure as mortar between the bricks, the apparent prevalence of lime in contact with the glass (as opposed to being in contact with the clay ceramic) leads us to suspect that the tank holding the glass indeed had a lime parting layer, which would also have served to insulate the clay bricks and molten glass 
from each other. For reaction of the glass with the structural lime materials to explain the slope of the correlation observed between iron oxide and lime, a $\mathrm{CaO} / \mathrm{Fe}_{2} \mathrm{O}_{3}$ ratio of around 20 would be required (Fig. 6, neglecting outlier sample 12). Lime-rich ceramic samples 8c and $16 \mathrm{c}$ have $\mathrm{CaO} / \mathrm{Fe}_{2} \mathrm{O}_{3}$ ratios of c.19 and 21 respectively and are consistent with this.

The low numbers of moils recovered at 'Aqir and at other workshops in the region (e.g. Hagolan Street, Tel Aviv; Freestone et al., 2015) suggests that even when located close to the centres of raw glass production, the waste materials of secondary workshops were carefully collected for recycling. For comparison, a Roman glass workshop in London, UK which appears to have been abandoned without a final collection of the waste yielded 6400 moil fragments (Wardle et al., 2015, pp. 54). The evidence for the transportation of secondary production waste in the Ma'agan Mikhael B wreck (Natan et al., 2020) supports this view. The glass workers are likely to have recycled most of the waste glass material which was not incorporated into vessels. However, the glass that stuck to the furnace floor and walls could not easily be separated without serious contamination. It is therefore reasonable to suggest that the waste glass that we have analysed would have been more severely contaminated than the glass in the centre of the tank which was blown into products. In view of this we have looked for evidence in the literature that this form of contamination has affected vessel compositions. While such evidence cannot be recognised in every assemblage, the compositional distribution of vessels in Apollonia-type glass from Cyprus, analysed by Ceglia et al., 2015, Ceglia et al., 2019, shows a marked elongation in the $\mathrm{Fe}_{2} \mathrm{O}_{3}-\mathrm{CaO}$ direction, which corresponds to the $\mathrm{Fe}_{2} \mathrm{O}_{3}-\mathrm{CaO}$ trend seen in the ${ }^{\circ}$ Aqir samples (Fig. 7 left). There is also a second, higher $\mathrm{Fe}_{2} \mathrm{O}_{3}$ trend evident in Fig. 7 (left); this, however, is related to elevated alumina (not illustrated), indicating contamination by clay ceramic. Ceglia et al. (2015) analysed their vessels using electron microprobe (EPMA) and repeated the analyses with LA-ICP-MS (Ceglia et al., 2019) and the effect is shown by both datasets (Fig. 7 left). Furthermore, glasses that had low levels of transition elements and were therefore considered by Ceglia et al. (2019) to show least evidence for recycling, also show least contamination by iron oxide and lime (Fig. 7 left). This is consistent with an increase in contamination through repeated re-melting and contact with the furnace materials.

We have also looked for indication of contamination in the trace element contents of the glass from Cyprus. If the mortar in the furnace had been made by burning limestone, it would have had a lower $\mathrm{Sr} / \mathrm{CaO}$ ratio than the glass in which the lime was derived from marine shell 
fragments in the glassmaking sand (Freestone et al., 2003). The contaminated glass might therefore be expected to show a lower $\mathrm{Sr} / \mathrm{CaO}$ ratio. However, while Fig. 7 (right) suggests that most of the glass with high $\mathrm{CaO}$ and showing evidence for recycling also has lower $\mathrm{Sr} / \mathrm{CaO}$, it is far from conclusive. This may be because the effects of the contamination are hidden by the scatter of the $\mathrm{Sr} / \mathrm{CaO}$ ratios of the glass but, alternatively, the mortar may have been produced by burning shell or kurkar (the regional name for lithified beach sand on the Levantine coast). More work would be needed to investigate the trace elements in the mortars of the furnace, to resolve this issue.
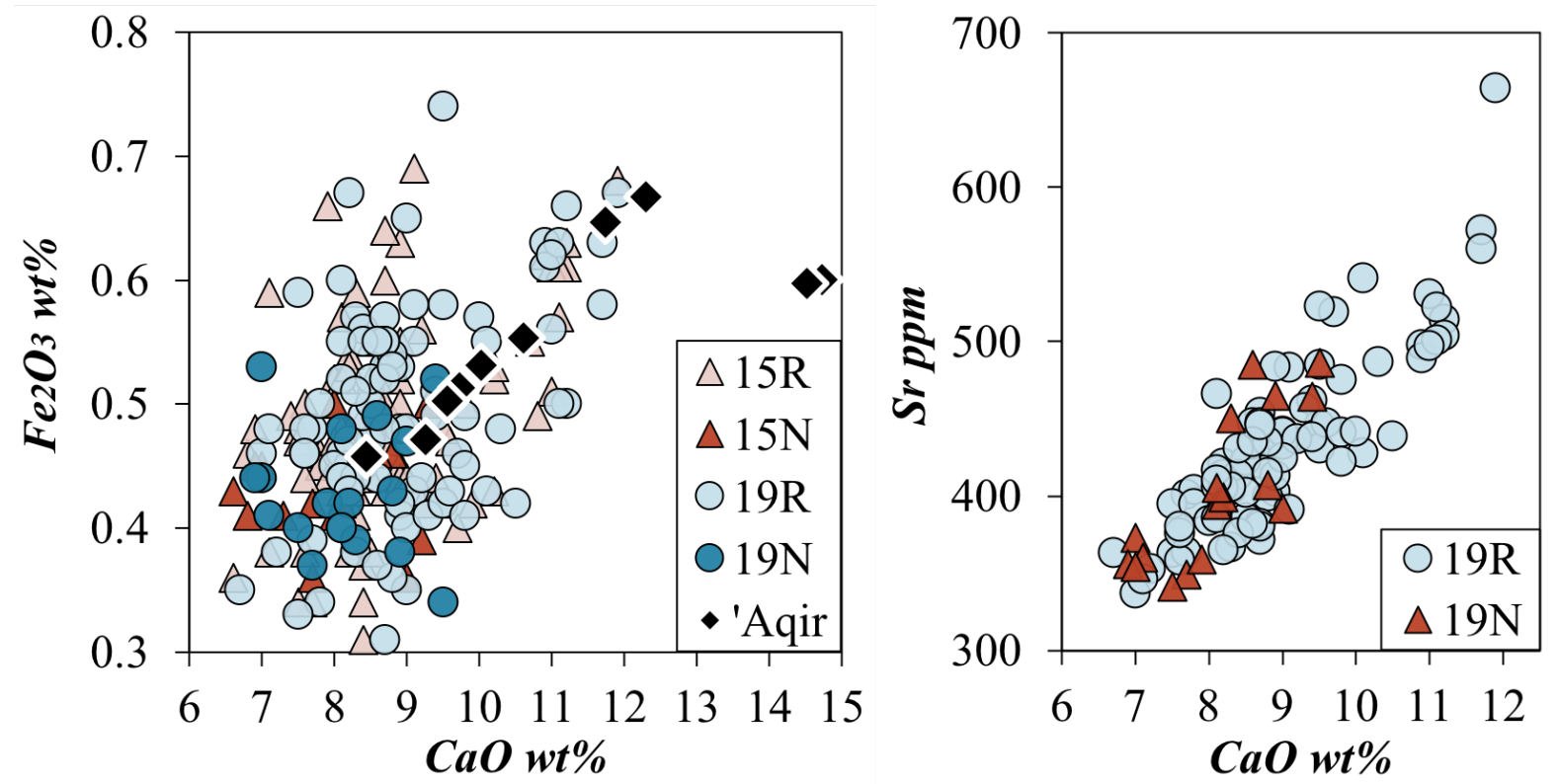

Fig. 7 Left: Bivariate plot of iron oxide and lime contents of glass production samples from 'Aqir (this study) compared with Apollonia type glass from Cyprus, data of Ceglia et al., 2015, Ceglia et al., 2019. Samples prefixed 15 are EPMA data, samples prefixed 19 are LA-ICP-MS data. R indicates glass with evidence for recycling in the form of elevated transition metals and $\mathrm{N}$ indicates glass with no evidence for of recycling. It is observed that the glasses with no evidence for recycling (dark symbols) typically have lower $\mathrm{Fe}_{2} \mathrm{O}_{3}$ and $\mathrm{CaO}$ contents; Right: Bivariate plot of strontium and lime contents of Apollonia type glass from Cyprus, data of Ceglia et al. (2019). 19R = glass with evidence for recycling; $19 \mathrm{~N}=$ glass with no evidence for of recycling.

\subsection{Chronology}

The furnace is dated by the excavator to be no earlier than the late third century CE on the basis of an associated burnt follis (coin) dated to 294-298 CE. The presence of bag-shaped 
jars dated to the late fourth - early fifth century in the furnace structure suggests that the furnace was operating in this period (Marmelstein, 2016). This at first appears to be at variance with the identification of the glass-working waste as Apollonia type glass, as the Apollonia furnaces which have been excavated are dated to the sixth-seventh centuries. However, Apollonia-type glass is known in the fifth century from elsewhere (e.g. Série 3.3 of Foy et al., 2003, Levantine I of Rehren and Cholakova, 2014) and at present there is a chronological gap incorporating the fifth century between the known Levantine glass making sites of Jalame and Apollonia (Freestone, 2020). Therefore, the Apollonia-type glass associated with the "Aqir furnace is not inconsistent with a late fourth - early fifth century date. It may represent glass made in the Apollonia region earlier than the excavated installations or glass of similar composition from elsewhere on the Levantine coast.

Glass vessels GV-1, GV-2 and GV-3 found close to the furnace are of well-known compositional groups broadly consistent with their typological dating to the fourth century or earlier; they are of compositions which differ from the Apollonia-type of the waste products. One possibility is that they were pieces collected to be recycled but this is speculative.

\section{Conclusion}

The present study confirms the potential of the analysis of glass workshop debris to provide useful information but also the complexities of interpretation of this type of assemblage.

The presence of glass vessels associated with the furnace which were of a different compositional type to the glass being melted indicates the need for caution in relating the production of glass forms to associated furnace structures without supporting analytical evidence.

Although made of a clay which was not particularly refractory, the ceramics contain several tens of percent of quartz, probably added to reduce thermal shrinkage and the associated stresses, and were able operate at temperatures of around $1100^{\circ} \mathrm{C}$. Mortar was applied either to fill the gaps between mudbricks or to line the furnace as a parting layer, but unfortunately the recovered debris does not allow the unambiguous discrimination of these two possibilities, although given the relative abundance of fragments with both high lime ceramic and glass, a parting layer seems most likely. The use of a lime parting layer would be paralleled in glass making materials recovered from Late Bronze Age Egypt (Merkel and 
Rehren, 2007; Smirniou and Rehren, 2016) and might suggest a long-lasting regional tradition. At 'Aqir, the glass interacted with the lime and allowed the identification for the first time in the Levant of a distinctive type of contamination. A review of available compositional data in the literature indicates a similar compositional pattern in contemporary glass vessels on Cyprus. It may be characteristic of a particular furnace technology common to the two regions, or alternatively indicate the export of cullet for recycling from Israel. In view of the association of the contamination in the Cypriot assemblage with evidence for glass recycling, the latter seems likely. Failure to recognise similar trends in other data for Apollonia glass (e.g. Phelps et al., 2016) may reflect chronological or geographical issues. It may be that other glass furnaces were lined with lime which had a low content of $\mathrm{Fe}_{2} \mathrm{O}_{3}$, so that the trend observed here does not occur in every assemblage. It is likely that contamination of the glass with lime did not only occur due to diffusion from the walls of the furnace into the tank; thin layers of parting material attached to glass broken out of failed furnaces for re-use would have added significant amounts of lime to batches of glass in which they were included. Where it occurs, this type of contamination is likely to complicate attempts to subdivide vessel assemblages by composition.

\section{Acknowledgements}

Access to the material was kindly facilitated by the excavator, Y. Marmelstein and the Israel Antiquities Authority is kindly acknowledged for permission to analyse the samples. We thank Drs. Tom Gregory, Agnese Benzonelli, Umberto Veronesi and Rahil Alipour for technical advice and assistance. The referees are thanked for their helpful comments. 


\section{Appendix A: List of Samples}

Table A.1 List of Samples

\begin{tabular}{|c|c|c|c|c|c|c|c|}
\hline No. & Location & Area & $\begin{array}{l}\text { Fig. No. on } \\
\text { Report }\end{array}$ & Type & Colour & Description & $\begin{array}{l}\text { Sample } \\
\text { Preparation }\end{array}$ \\
\hline 1 & L39 & A2 & $21: 9$ & ceramic & blackish-grey & $\begin{array}{l}\text { Chunk of brick from the hard accumulation inside the } \\
\text { furnace, probably the roof. }\end{array}$ & $\begin{array}{l}\text { thin section, } \\
\text { polished block }\end{array}$ \\
\hline 2 & L39 & A2 & $21: 10$ & ceramic & $\begin{array}{l}\text { yellowish brown, } \\
\text { inside red }\end{array}$ & $\begin{array}{l}\text { Drop of very light chunk of grey spongy material from the } \\
\text { hard accumulation inside the furnace. }\end{array}$ & polished block \\
\hline 3 & L39 & A2 & $21: 3$ & ceramic & red & $\begin{array}{l}\text { Red brick similar to those used in construction, from the } \\
\text { hard accumulation inside the furnace. }\end{array}$ & polished block \\
\hline 4 & L39 & $\mathrm{A} 2$ & $21: 4$ & ceramic & blackish-grey & $\begin{array}{l}\text { Fired brick with protruding edges (probably from the } \\
\text { corner) of the hard accumulation inside the furnace, was } \\
\text { baked in high temperature. }\end{array}$ & $\begin{array}{l}\text { thin section, } \\
\text { polished block }\end{array}$ \\
\hline 5 & L37 & A2 & $\begin{array}{l}21: 6 \text { bottom } \\
\text { right }\end{array}$ & ceramic & $\begin{array}{l}\text { Two pieces. 5b: } \\
\text { blackish-grey; 5r: red }\end{array}$ & Glazed mud-brick, one side glazed, inside red. & $\begin{array}{l}\text { thin section, } \\
\text { polished block }\end{array}$ \\
\hline 6 & L37 & A2 & $21: 6$ top left & ceramic & blackish-grey & Very heavy black chunk. & $\begin{array}{l}\text { thin section, } \\
\text { polished block }\end{array}$ \\
\hline 7 & L37 & A2 & $\begin{array}{l}21: 8 \text { top } \\
\text { right, big } \\
\text { chunk }\end{array}$ & ceramic & dark grey & $\begin{array}{l}\text { Big chunk partly glazed, looks like it was fired several } \\
\text { times. White layer outside. }\end{array}$ & $\begin{array}{l}\text { thin section, } \\
\text { polished block }\end{array}$ \\
\hline 8 & L2 & $\mathrm{A}$ & $\begin{array}{l}22: 4 \text { top } \\
\text { right }\end{array}$ & $\begin{array}{l}\text { glass with } \\
\text { ceramic }\end{array}$ & $\begin{array}{l}\text { 8c: light brown; } 8 \mathrm{~g} \text { : } \\
\text { yellowish-green }\end{array}$ & $\begin{array}{l}\text { Glass with furnace debris, yellowish-green glass at the edge } \\
\text { of the chunk. }\end{array}$ & polished block \\
\hline
\end{tabular}




\begin{tabular}{|c|c|c|c|c|c|c|c|}
\hline 9 & $\mathrm{~L} 2$ & A & $\begin{array}{l}22: 4 \text { top left } \\
\text { second }\end{array}$ & $\begin{array}{l}\text { glass (with } \\
\text { ceramic) }\end{array}$ & greenish-blue & Chunk of greenish-blue glass with debris. & polished block \\
\hline 10 & $\mathrm{~L} 23$ & $\mathrm{~A} 2$ & $21: 13$ & ceramic & dark grey & Glazed brick, probably part of the furnace's ceiling. & $\begin{array}{l}\text { thin section, } \\
\text { polished block }\end{array}$ \\
\hline 11 & L22 & $\begin{array}{l}\text { between } \\
\text { A2A3 }\end{array}$ & $23: 1$ & glass (moil) & colourless & Moil, found next to Samples GV-3 and GV-4. & polished block \\
\hline 12 & L11 & $\mathrm{A}$ & $\begin{array}{l}22: 3 \text { top left } \\
\text { second }\end{array}$ & glass & greenish-blue & Mixed with the kiln's waste. & $\begin{array}{l}\text { polished blocks } \\
\left(12 \_1,12 \_2\right)\end{array}$ \\
\hline 13 & L11 & $\mathrm{A}$ & $\begin{array}{l}22: 3 \text { top left } \\
\text { first }\end{array}$ & $\begin{array}{l}\text { glass with } \\
\text { ceramic }\end{array}$ & $\begin{array}{l}\text { 13g: creamy-white; } \\
\text { 13c: greenish-blue }\end{array}$ & Complete chunk: floor + glass. & polished block \\
\hline 14 & L47 & $\mathrm{A}$ & $22: 7$ & $\begin{array}{l}\text { glass with } \\
\text { ceramic }\end{array}$ & $\begin{array}{l}\text { light brown \& light } \\
\text { green }\end{array}$ & $\begin{array}{l}\text { Debris from furnace with glass penetrated and filled the } \\
\text { cracks in the brick. }\end{array}$ & $\begin{array}{l}\text { thin section, } \\
\text { polished block }\end{array}$ \\
\hline 15 & L4 & $\mathrm{A}$ & $22: 6$ & $\begin{array}{l}\text { glass (with } \\
\text { ceramic) }\end{array}$ & yellowish-green & Glass with furnace debris. & $\begin{array}{l}\text { polished blocks } \\
\left(15 \_1,15 \_2\right)\end{array}$ \\
\hline 16 & L3 & $\mathrm{A}$ & $22: 5$ top left & $\begin{array}{l}\text { glass with } \\
\text { ceramic }\end{array}$ & $\begin{array}{l}\text { 16g: greenish-blue; } \\
\text { 16c: light brown }\end{array}$ & Glass with small wall fragment. & polished block \\
\hline 17 & L49 & $\mathrm{A}$ & $23: 5$ & glass & greenish-blue & Glass chunk. & polished block \\
\hline GV-1 & L44 & $\mathrm{A} 2$ & $24: 1$ & $\begin{array}{l}\text { glass } \\
\text { (vessel) }\end{array}$ & colourless & $\begin{array}{l}\text { Beaker body fragment with white creamy weathering layer } \\
\text { on surface, its appearance looks like of the } 2 \text { nd-3rd } \\
\text { centuries CE. }\end{array}$ & $\begin{array}{l}\text { polished blocks } \\
\left(\mathrm{GV}-1 \_1, \mathrm{GV}-1 \_2\right)\end{array}$ \\
\hline GV-2 & L11 & $\begin{array}{l}\text { between } \\
\text { A2A3 }\end{array}$ & $24: 8$ & $\begin{array}{l}\text { glass } \\
\text { (vessel) }\end{array}$ & greenish-blue & $\begin{array}{l}\text { Fragments from the upper part of a bottle with black pitted } \\
\text { weathering. }\end{array}$ & polished block \\
\hline GV-3 & L22 & between & $24: 6$ & glass & slightly greenish-blue & A solid base with silvery and black weathering, found & polished block \\
\hline
\end{tabular}




\begin{tabular}{|l|l|l|l|l|l|l|l|}
\hline & & A2A3 & & (vessel) & & together with Samples 11 and GV-4. \\
\hline GV-4 & L22 & $\begin{array}{l}\text { between } \\
\text { A2A3 }\end{array}$ & $24: 7$ & $\begin{array}{l}\text { glass } \\
\text { (vessel) }\end{array}$ & greenish-blue & $\begin{array}{l}\text { Fragment of a small bottle that was distorted by the heat, } \\
\text { found next to Samples 11 and GV-3. }\end{array}$ & $\begin{array}{l}\text { polished blocks } \\
\text { (GV-4_1, GV-4_2) }\end{array}$ \\
\hline
\end{tabular}




\section{Appendix B: Illustration of Samples}
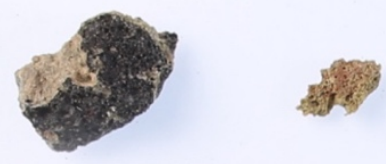

1

5

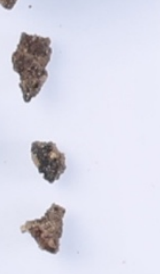

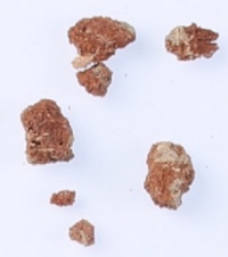

3

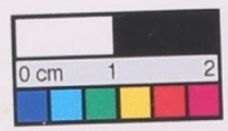

6

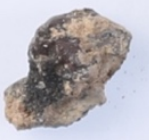

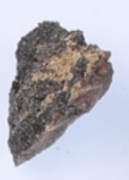

4
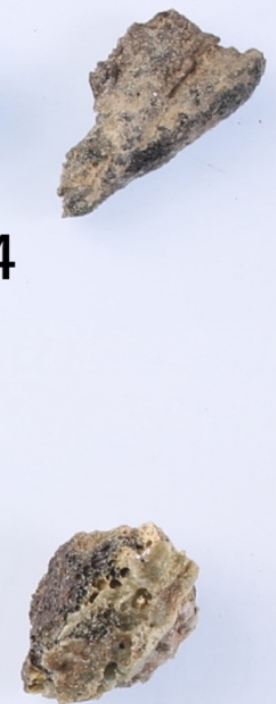

7

Fig. B.1 Ceramic samples

8

8

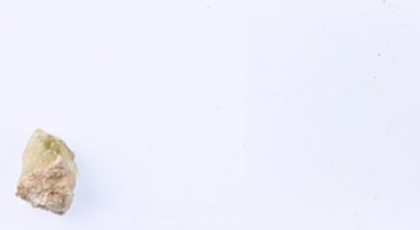

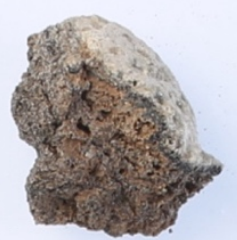

10

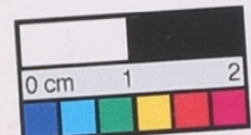

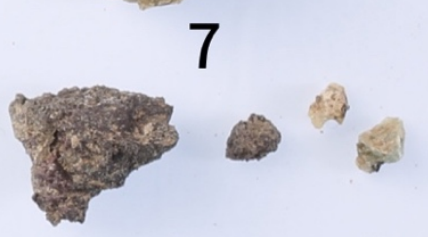




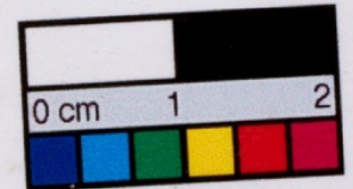

Fig. B.3 Glass chunks

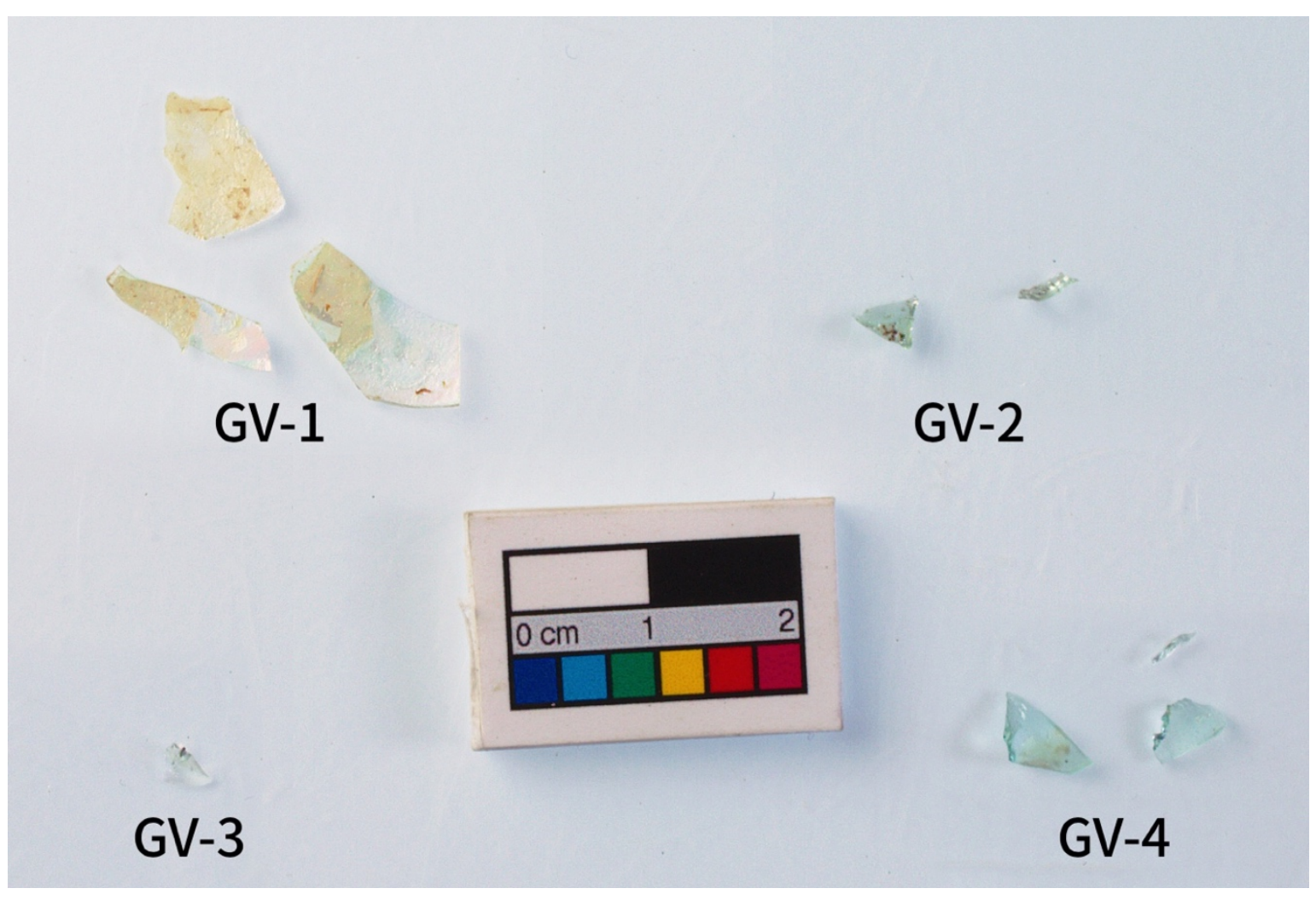

Fig. B.4 Glass vessel fragments

Photo by Chen Chen. 


\section{References}

ABD-ALLAH, R. 2010. Chemical Characterisation and Manufacturing Technology of Late Roman to Early Byzantine Glass from Beit Ras/Capitolias, Northern Jordan. Journal of Archaeological Science, 37, pp. 1866-1874.

AL-BASHAIREH, K., AL-MUSTAFA, S., FREESTONE, I. C. \& AL-HOUSAN, A. Q. 2016 a. Composition of Byzantine Glasses from Umm el-Jimal, Northeast Jordan: Insights into Glass Origins and Recycling. Journal of Cultural Heritage, 21, pp. 809-818.

AL-BASHAIREH, K., ALAMA, E. \& AL-HOUSAN, A. Q. 2016b. Analytical and Technological Study of Roman, Byzantine and Early Islamic (Umayyad) Glasses from Al-Fudein Archaeological Site, Jordan. Mediterranean Archaeology and Archaeometry, 16(1), pp. 257-268.

ALI, N. \& ABD-ALLAH, R. 2015. The Authentication and Characterization of Glass Objects Excavated from Tell es-Sukhnah, Jordan. Mediterranean Archaeology \& Archaeometry, 15(2), pp. $39-50$

ARES, J. D. J., GUIRADO, A. V.-E., GUTIÉRREZ, Y. C. \& SCHIBILLE, N. 2019. Changes in the supply of eastern Mediterranean glasses to Visigothic Spain. Journal of Archaeological Science, 107, pp. 23-31.

BARFOD, G., FREESTONE, I., LICHTENBERGER, A., RAJA, R. \& SCHWARZER, H. 2018. Geochemistry of Byzantine and Early Islamic Glass from Jerash, Jordan: Typology, Recycling, and Provenance. Geoarchaeology, 33(6), pp. 623-640.

BARFOD, G.H., FREESTONE, I.C., LESHER, C.E., LICHTENBERGER, A. \& RAJA, R. 2020. 'Alexandrian'glass confirmed by hafnium isotopes. Scientific reports, 10(1), 11322. https://doi.org/10.1038/s41598-020-68089-w

BRILL, R. 1988. Scientific Investigations of the Jalame Glass and Related Finds. In: WEINBERG, G. (ed.) Excavations at Jalame: site of a glass factory in late Roman Palestine. Columbia: University of Missouri Press. pp. 257-294.

BRILL, R. 1999. Chemical analyses of early glasses, New York, Corning Museum of Glass.

CEGLIA, A., COSYNS, P., NYS, K., TERRYN, H., THIENPONT, H. \& MEULEBROECK, W. 2015. Late Antique Glass Distribution and Consumption in Cyprus: A Chemical Study. Journal of Archaeological Science, 61, pp. 213-222.

CEGLIA, A., COSYNS, P., SCHIBILLE, N. \& MEULEBROECK, W. 2019. Unravelling Provenance and Recycling of Late Antique Glass from Cyprus with Trace Elements. Archaeological and Anthropological Sciences, 11(1), pp. 279-291.

DONNER, H. 1992. The mosaic map of Madaba: An introductory guide, Peeters Publishers.

DUNGWORTH, D. 2008. Glass-ceramic reactions in some post-medieval crucibles: an instrumental analysis study of archaeological samples. Glass Technology-European Journal of Glass Science and Technology Part A, 49(4), pp. 157-167.

EL-KHOURI, L. 2014. Glass Production in the Early Byzantine Period (4th-7th Century) at Gadara (Umm Qais), Jordan, Area W, 2011 Season of Excavation. Levant, 46(1), pp. 89-97.

ERAMO, G. 2005. THE MELTING FURNACE OF THE DERRIÈRE SAIROCHE GLASSWORKS (COURT, SWISS JURA): HEAT-INDUCED MINERALOGICAL TRANSFORMATIONS AND THEIR TECHNOLOGICAL SIGNIFICANCE. Archaeometry, 47(3), pp. 571-592. 
ERAMO, G. 2006. The glass-melting crucibles of Derrière Sairoche (1699-1714 AD, Ct. Bern, Switzerland): a petrological approach. Journal of Archaeological Science, 33(3), pp. 440-452.

FILIPE, JOURNOIS, M., STORY, R., GARDINER, J., RUMP, H., BIRD, A., FRANK, LIMA, A., CANO, J., LEONEL, J., SAMPSON, T., WELSH, B., READES, J., KOMAROV, O., KONG, Q., ODOVAD, DUMAS, R., HARRIS, G., CROSBY, A., KENMATSU4, NOGUEIRA, T. P., WILSON, N., GIESSE, A., SOYMSK, SIGNELL, R., DUKE, J., PATIL, A., CHANG, T., SGVANDIJK \& PAH, A. 2018. python-visualization/folium: v0.6.0 [Online]. Available: http://doi.org/10.5281/zenodo.1344457 [Accessed 22 August 2018].

FOSTER, H. \& JACKSON, C. 2009. The Composition of 'Naturally Coloured' Late Roman Vessel Glass from Britain and the Implications for Models of Glass Production and Supply. Journal of Archaeological Science, 36(2), pp. 189-204.

FOY, D., PICON, M., VICHY, M. \& THIRION-MERLE, V. 2003. Caractérisation des verres de la fin de l'Antiquité en Méditerranée occidentale: l'émergence de nouveaux courants commerciaux. In: FOY, D. \& NENNA, M. (eds.) Échanges et commerce du verre dans le monde antique. Montagnac: Éditions Monique Mergoil. pp. 41-86.

FREESTONE, I. 2020. Apollonia Glass and Its Markets: An Analytical Perspective. (in press) In: TAL, O (2020) Apollonia-Arsuf: Final Report of the Excavations: Volume II: Excavations Outside the Medieval Town Walls. Tel Aviv. pp. 347-354.

FREESTONE, I. C. 2021. Glass Production in the First Millennium CE: A Compositional Perspective. In: KLIMSCHA, F. (ed.) |Ancient Glass and Glass Production. Berlin Studies of the Ancient World 67 Edition TOPOI

FREESTONE, I., JACKSON-TAL, R. \& TAL, O. 2008. Raw Glass and the Production of Glass Vessels at Late Byzantine Apollonia-Arsuf, Israel. Journal of Glass Studies, 50, pp. 67-80.

FREESTONE, I., LESLIE, K., THIRLWALL, M. \& GORIN-ROSEN, Y. 2003. Strontium Isotopes in the Investigation of Early Glass Production: Byzantine and Early Islamic Glass from the Near East. Archaeometry, 45(1), pp. 19-32.

FREESTONE, I., POLITIS, K. \& STAPLETON, C. 2001. The Byzantine Glazed Pottery from Deir 'Ain 'Abata, Jordan. Céramique Byzantine 2001, pp. 197-205.

FREESTONE, I. \& TITE, M. 1986. Refractories in the Ancient and Preindustrial World. In: KINGERY, W. \& LENSE, E. (eds.) High-Technology Ceramics: Past, Present, and Future-The Nature of Innovation and Change in Ceramic Technology. Westerville: The American Society. pp. $35-63$.

FREESTONE, I. C., GORIN-ROSEN, Y. \& HUGHES, M. J. 2000. Primary Glass from Israel and the Production of Glass in Late Antiquity and the Early Islamic Period. Publications de la Maison de l'Orient et de la Méditerranée, 33(1), pp. 65-83.

FREESTONE, I.C., JACKSON-TAL, R.E., TAL, O. \& TAXEL, I. 2015. Glass Production at an Early Islamic Workshop in Tel Aviv, Journal of Archaeological Science, 62, pp. 45-54.

FUKUDA, K. AND MAKI, I., 1989. Orientation of $\beta-\mathrm{Ca}_{2} \mathrm{SiO}_{4}$ Solid Solution Lamellae Formed in the Host $\alpha$-phase. Cement and Concrete Research, 19(6), pp. 913-918.

GANIO, M., BOYEN, S., FENN, T., SCOTT, R., VANHOUTTE, S., GIMENO, D. \& DEGRYSE, P. 2012. Roman Glass Across the Empire: An Elemental and Isotopic Characterization. Journal of Analytical Atomic Spectrometry, 27(5), pp. 743-753. 
GERTH, K., WEDEPOHL, K. \& HEIDE, K. 1998. Experimental Melts to Explore the Technique of Medieval Woodash Glass Production and the Chlorine Content of Medieval Glass Types. Chemie Der Erde-Geochemistry, 58(3), pp. 219-232.

GLIOZZO, E., 2017. The composition of colourless glass: a review. Archaeological and Anthropological Sciences, 9(4), pp. 455-483.

GORIN-ROSEN, Y. 2000. The Ancient Glass Industry in Israel: Summary of the Finds and New Discoveries. La Route du verre. Ateliers primaires et secondaires du second millénaire av. J.-C. au Moyen Âge. Lyon: Maison de l'Orient et de la Méditerranée Jean Pouilloux. pp. 49-63.

GORIN-ROSEN, Y. 2016. Waste from a Glass Workshop. In: Marmelstein, Y. ‘Aqir. 2016 [Online]. Available: http://www.hadashot-esi.org.il/report_detail_eng.aspx?id=25014\&mag_id=124 [Accessed 28 March 2018].

GREATREX, G. \& LIEU, S. N. 2005. The Roman Eastern Frontier and the Persian Wars AD 363628, New York, Routledge.

GROSS, S. 2016. Petrographic atlas of the Hatrurim Formation, Jerusalem, Geological Survey of Israel.

HENDERSON, J., CHALLIS, K., O'HARA, S., MCLOUGHLIN, S., GARDNER, A. \& PRIESTNALL, G. 2005. Experiment and Innovation: Early Islamic Industry at al-Raqqa, Syria. Antiquity, 79(303), pp. 130-145.

HENDERSON, J., MCLOUGHLIN, S. \& MCPHAIL, D. 2004. Radical Changes in Islamic Glass Technology: Evidence for Conservatism and Experimentation with New Glass Recipes from Early and Middle Islamic Raqqa, Syria. Archaeometry, 46(3), pp. 439-468.

HUNAULT, M. O., VINEL, V., CORMIER, L. \& CALAS, G. 2017. Thermodynamic insight into the evolution of medieval glassworking properties. Journal of the American Ceramic Society, 100(6), pp. 2363-2367.

JACKSON, C. M., COOL, H. \& WAGER, E. C. 1998. The manufacture of glass in Roman York. Journal of Glass Studies, pp. 55-61.

JACKSON, C., JOYNER, L., BOOTH, C., DAY, P., WAGER, E. \& KILIKOGLOU, V. 2003. Roman glass-making at Coppergate, York? Analytical evidence for the nature of production. Archaeometry, 45(3), pp. 435-456.

JACKSON, C. \& PAYNTER, S. 2016. A Great Big Melting Pot: Exploring Patterns of Glass Supply, Consumption and Recycling in Roman Coppergate, York. Archaeometry, 58(1), pp. 68-95.

KAMBER, B. S., GREIG, A. \& COLLERSON, K. D. 2005. A new estimate for the composition of weathered young upper continental crust from alluvial sediments, Queensland, Australia. Geochimica et Cosmochimica Acta, 69(4), pp. 1041-1058.

MARMELSTEIN, Y. 2016. 'Aqir [Online]. Israel Antiquities Authority. Available: $\mathrm{http} / / /$ www.hadashot-esi.org.il/report_detail_eng.aspx?id=25014\&mag_id=124 [Accessed 28 March 2018].

MERKEL, S. \& REHREN, T. 2007. Parting Layers, Ash Trays and Ramesside Glassmaking: An Experimental Study. In: PUSCH, E. \& REHREN, T. (eds.). Verlag Gebrüder Gerstenberg. pp. 207225.

MIDDLETON, A., FREESTONE, I. \& LEESE, M. 1985. Textural Analysis of Ceramic Thin Sections: Evaluation of Grain Sampling Procedures. Archaeometry, 27(1), pp. 64-74. 
NATAN, E., GORIN-ROSEN, Y. \& CVIKEL, D. 2020. Maritime trade in Early Islamic-period glass: New evidence from the Ma'agan Mikhael B shipwreck. Journal of Archaeological Science: Reports, this volume.

PAYNTER, S. 2008. Experiments in the Reconstruction of Roman Wood-fired Glassworking Furnaces: Waste Products and Their Formation Processes. Journal of Glass Studies, pp. 271-290.

PHELPS, M., FREESTONE, I., GORIN-ROSEN, Y. \& GRATUZE, B. 2016. Natron Glass Production and Supply in the Late Antique and Early Medieval Near East: The Effect of the Byzantine-Islamic Transition. Journal of Archaeological Science, 75, pp. 57-71.

QUINN, P. S. 2013. Ceramic petrography - the interpretation of archaeological pottery and related artefacts in thin section, Oxford, Archaeopress.

REHREN, T. 1997. Ramesside glass-colouring crucibles. Archaeometry, 39(2), pp. 355-368.

REHREN, T. \& CHOLAKOVA, A. 2014. Glass supply and consumption in the late Roman and early Byzantine site Dichin, northern Bulgaria. In: KELLER, D., PRICE J. \& JACKSON C. (eds.) Neighbours and successors of Rome-Traditions of glass production and use in Europe and the Middle East in the later 1st millennium AD. Oxford: Oxbow Books, pp.83-94.

REHREN, T., MARII, F., SCHIBILLE, N., STANFORD, L. \& SWAN, C. 2010. Glass supply and circulation in early Byzantine southern Jordan. In: DRAUSCHKE, J. \& KELLER, D. (eds.) Glass in Byzantium: Production, Usage, Analyses. Mainz: Römisch- Germanischen Zentralmuseums. pp. 6582.

REHREN, T. \& PERINI, E. 2005. The glass furnace debris. In: SEELEY, F. \& DRUMMONDMURRAY, J. (eds.) Roman pottery production in the Walbrook valley: excavations at 20-28 Moorgate, City of London, 1998-2000. London: Museum of London Archaeology Service. pp. 184186.

ROEDDER, E. 1959. Silicate melt systems. Physics and Chemistry of the Earth, 3, pp. 224-297.

ROWAN, E. 2015. Olive Oil Pressing Waste as a Fuel Source in Antiquity. American Journal of Archaeology, 119(4), pp. 465-482.

SCHIBILLE, N., GRATUZE, B., OLLIVIER, E. \& BLONDEAU, É. 2019. Chronology of Early Islamic Glass Compositions from Egypt. Journal of Archaeological Science, 104, pp. 10-18.

SCHIBILLE, N., STERRETT-KRAUSE, A. \& FREESTONE, I. 2017. Glass Groups, Glass Supply and Recycling in Late Roman Carthage. Archaeological and Anthropological Sciences, 9(6), pp. 1223-1241.

SILVESTRI, A., MOLIN, G. \& SALVIULO, G. 2008. The Colourless Glass of Iulia Felix. Journal of Archaeological Science, 35(2), pp. 331-341.

SMIRNIOU, M. \& REHREN, T. 2016. The Use of Technical Ceramics in Early Egyptian Glassmaking. Journal of Archaeological Science, 67, pp. 52-63.

SOKOL, E.V., KOKH, S.N., SHARYGIN, V.V., DANILOVSKY, V.A., SERYOTKIN, Y.V., LIFEROVICH, R., DEVIATIIAROVA, A.S., NIGMATULINA, E.N. AND KARMANOV, N.S., 2019. Mineralogical diversity of $\mathrm{Ca}_{2} \mathrm{SiO}_{4}$-bearing combustion metamorphic rocks in the Hatrurim Basin: Implications for storage and partitioning of elements in oil shale clinkering. Minerals, 9(8), p.465.

TAL, O., JACKSON-TAL, R. E. \& FREESTONE, I. C. 2004. New Evidence of the Production of Raw Glass at Late Byzantine Apollonia-Arsuf, Israel. Journal of Glass Studies, 46, pp. 51-66. 
TAL, O., JACKSON-TAL, R. E. \& FREESTONE, I. C. 2008. Glass from a Late Byzantine Secondary Workshop at Ramla (South), Israel. Journal of Glass Studies, 50, pp. 81-95.

TAYLOR, M. \& HILL, D. 2008. Experiments in the reconstruction of Roman wood-fired glassworking furnaces. Journal of Glass Studies, pp. 249-270.

TITE, M. 1999. Pottery Production, Distribution, and Consumption - the Contribution of the Physical Sciences. Journal of Archaeological Method and Theory, 6(3), pp. 181-233.

TURNER, W. E. S. 1954. Studies of Ancient Glass and Glass-Making Processes, Part I: Crucibles and Melting Temperatures Employed in Ancient Egypt at about 1370 BC. Journal of the Society of Glass Technology, 38, pp. 436T-444T.

WARDLE, A., FREESTONE, I., McKENZIE, M. and SHEPHERD, J. (2015) Glass working on the margins of Roman London: Excavations at 35 Basinghall Street, City of London, 2005. London: Museum of London Archaeology (MOLA Monograph).

WIEDENMANN, D., ZAITSEV, A.N., BRITVIN, S.N., KRIVOVICHEV, S.V. AND KELLER, J., 2009. Alumoakermanite, $(\mathrm{Ca}, \mathrm{Na})_{2}\left(\mathrm{Al}, \mathrm{Mg}, \mathrm{Fe}^{2+}\right)\left(\mathrm{Si}_{2} \mathrm{O}_{7}\right)$, a new mineral from the active carbonatitenephelinite-phonolite volcano Oldoinyo Lengai, northern Tanzania. Mineralogical Magazine, 73(3), pp.373-384.

WOLF, C. 1971. The Onomasticon of Eusebius Pamphili, compared with the Version of Jerome, and Annotated. Available: http://www.tertullian.org/fathers/eusebius_onomasticon_02_trans.htm [Accessed 17 July 2018]. 